\title{
Mafic intrusions, hydrothermal venting, and the basalt-sediment transition: Linking onshore and offshore examples from the North Atlantic igneous province
}

\author{
Syahreza S. Angkasa ${ }^{1}$, Dougal A. Jerram², John M. Millett ${ }^{3}$, Henrik H. Svensen ${ }^{1}$, Sverre Planke ${ }^{4}$, \\ Ross A. Taylor ${ }^{5}$, Nick Schofield ${ }^{5}$, and John Howell ${ }^{5}$
}

\begin{abstract}
The emplacement of large intrusive complexes into sedimentary basins can have profound effects on host sedimentary rocks including deformation, thermal aureole metamorphic reactions, alteration of fluid-flow pathways, and the formation of associated hydrothermal vent complexes (HVCs). These processes can in turn have major implications for petroleum systems on the local and regional scale, and can contribute to global climate change due to the production and outgassing of greenhouse gases, such as $\mathrm{CH}_{4}$ and $\mathrm{CO}_{2}$. Imaging these features and assessing their implications from seismic data beneath extrusive volcanic cover is challenging due to heterogeneities in the volcanic pile and at the basalt-sediment transition. We have evaluated combined field and laboratory petrophysical data from the Isle of Skye, Scotland, where we identify a seismic-scale example of extensive intrusions interacting with the base-basalt transition. We have also evaluated a unique onshore example of a linked sill and associated HVC cutting up through the lava sequence. We compare these field results with HVCs from reflection seismic data across the Vøring Marginal High, offshore Norway, where subbasalt saucer-shaped intrusions are also seen associated with HVCs cutting the lava sequence. Seismic imaging problems associated with the velocity heterogeneity of volcanic sequences, along with a historical lack of highquality 3D data in volcanic regions worldwide, is suggested as having largely precluded the identification of these features in the past. The under-representation of these hydrothermal vents in the literature has key implications for the future appraisal of intrusion-related outgassing effects on the global climate such as those related to the Palaeocene Eocene Thermal Maximum, along with subbasalt petroleum prospectivity where they may alter maturation and migration pathways.
\end{abstract}

\section{Introduction}

The emplacement of large volumes of predominantly mafic intrusions during the development of large igneous provinces (LIPs) (e.g., Jerram and Bryan, 2015), has many implications for understanding contemporaneous global climate change (e.g., Svensen et al., 2004, 2007; Ganino and Arndt, 2009) and petroleum exploration (e.g., Schutter, 2003; Delpino et al., 2009; Jerram, 2015). Large-scale intrusive complexes on continental margins can have global climatic implications related to the formation and outgassing of greenhouse gases, such as $\mathrm{CH}_{4}$ and $\mathrm{CO}_{2}$, into the oceans and atmosphere through hydrothermal vent complexes (HVCs) (e.g., Svensen et al., 2004, 2015; Aarnes et al., 2015). In addition, igneous intrusions may influence the maturation of source rocks and the production of hydrocarbons (Svensen et al., 2004; Aarnes et al., 2010, 2015; Witte et al., 2012; Iyer et al., 2013) along with the modification of migration pathways by compartmentalization and emplacement associated fracturing (Filho et al., 2008; Rateau et al., 2013). Moreover, intrusions may also form hydrocarbon traps, including forced folding (Schutter, 2003; Jackson et al., 2013) and may host intraintrusion hydrocarbon reservoirs (Witte et al., 2012; Barr and Cooper, 2013). To

\footnotetext{
${ }^{1}$ The University of Oslo, Centre for Earth Evolution and Dynamics (CEED), Oslo, Norway. E-mail: syahreza.s.a@gmail.com; hensven@geo.uio.no.

${ }^{2}$ The University of Oslo, Centre for Earth Evolution and Dynamics (CEED), Oslo, Norway and Dougal EARTH Ltd., Solihull, UK. E-mail: dougal@ dougalearth.com.

${ }^{3}$ VBPR AS, Oslo Science Park, Oslo, Norway and The University of Aberdeen, Department of Geology \& Petroleum Geology, Aberdeen, UK. E-mail: john.millett@vbpr.no.

${ }^{4}$ The University of Oslo, Centre for Earth Evolution and Dynamics (CEED) and VBPR AS, Oslo Science Park, Oslo, Norway. E-mail: planke@vbpr no.

${ }^{5}$ The University of Aberdeen, Department of Geology \& Petroleum Geology, Aberdeen, UK. E-mail: rossalexander1988@gmail.com; n.schofield@ abdn.ac.uk; john.howell@abdn.ac.uk.

Manuscript received by the Editor 30 September 2016; revised manuscript received 13 February 2017; published online 15 May 2017. This paper appears in Interpretation, Vol. 5, No. 3 (August 2017); p. SK83-SK101, 11 FIGS., 1 TABLE.

http://dx.doi.org/10.1190/INT-2016-0162.1. @ 2017 Society of Exploration Geophysicists and American Association of Petroleum Geologists. All rights reserved.
} 
effectively appraise the contribution of intrusions to a basins history or past climatic forcing, the identification of intrusions and associated HVCs in the subsurface is of paramount importance.

There are increasing amounts of seismic data becoming available from volcanic margins that image volcanic stratigraphy and associated intrusions (e.g., Jerram et al., 2009; Planke et al., 2015). In the subsurface, large intrusions may often be easily imaged as the highest amplitude reflectors in a sedimentary package (e.g., Planke et al., 2005); however, imaging sills may become more challenging at greater depths, with poor-quality data and where the sill thickness reduces (e.g., Smallwood and Maresh, 2002; Schofield et al., 2015). In the case of extrusive volcanic sequences, their highly heterogeneous velocity structure can cause extensive scattering of seismic waves, and it is therefore notoriously difficult to image volcanic rocks along with the stratigraphy and structures present beneath the basalt cover (Gallagher and Dromgoole, 2007; Davison et al., 2010). In this context, the presence, significance, and implications of intrusions and associated HVCs (e.g., Svensen et al., 2004) within the basalt-covered basinal regions of volcanic rifted margins are to date poorly constrained. The identification of HVCs associated with intrusions is of particular importance because they provide direct evidence for the creation of migration pathways and the passage of potential greenhouse gases to the atmosphere (Svensen et al., 2004).

An associated challenge in basins with volcanic cover is the identification and interpretation of the basalt-sediment transition (Davison et al., 2010). Where variations in the eruption environment at the onset of volcanism occur, the physical properties of the volcanic facies, as well as the facies distribution, can vary markedly (e.g., Nelson et al., 2009; Watton et al., 2014; Jerram et al., 2016a, 2016b). Understanding the likely heterogeneities in volcanic facies and the associated physical properties at the basalt-sediment transition is therefore important for identifying the transition in seismic data and, by implication, interpreting subbasalt features such as intrusions and associated HVCs.

Within this study, we investigate key field- and seismic-based examples of intrusions and associated HVC features emplaced in close proximity to the base-basalt transition from onshore (Isle of Skye, Scotland) and offshore (Vøring Basin, Norwegian Margin). We present field-based examples of intrusion-induced forced folding, a process whereby magma emplacement locally uplifts overburden strata (e.g., Pollard and Jonhson, 1973; Trude et al., 2004; Hansen and Cartwright, 2006; Jackson et al., 2013) along with evidence for onshore and offshore occurrences of sills linked to HVCs cutting through lava sequences in the North Atlantic igneous province (NAIP). Additionally, we present new petrophysical data profiles across the base-basalt transition in different onshore settings to help quantify the observed heterogeneities. We aim at improving characterization and integration of onshore examples with offshore remote sensing data to highlight the importance of intrusionrelated influences on petroleum systems and climatic forcing within basalt-covered basinal areas worldwide.

\section{Study areas \\ North Atlantic igneous province}

Continental break-up in the North Atlantic region between northwest Europe and East Greenland during the Palaeogene was accompanied by widespread volcanism associated with NAIP (e.g., Saunders et al., 1997; Hansen et al., 2009). Extensive lava fields, hydrovolcanic sequences, and subsurface intrusive complexes were emplaced on either side of the developing continental rift zone from the Late Paleocene to the Early Eocene followed by seafloor spreading. Widespread voluminous volcanism in the region is widely attributed to excess mantle temperatures (Hole and Millett, 2016) associated with a proto-Iceland thermal anomaly (often termed the "Iceland plume"), which initiated the first main phase of volcanism at the peripheries of the NAIP province (e.g., Scottish Hebrides and West Greenland) from approximately $62 \mathrm{Ma}$ (Hole et al., 2015). The main phase of volcanic activity was focused along the protorift zone from approximately 57-55 Ma accompanying continental break-up from approximately 55 Ma onward (Saunders et al., 1997; Jerram and Widdowson, 2005).

\section{Onshore: Isle of Skye, Scotland}

The volcanic rocks exposed on the Isle of Skye form part of the British Palaeogene Igneous Province, part of the larger NAIP (Saunders et al., 1997). The Isle of Skye comprises rock units ranging in age from Precambrian to the Quaternary and is situated between two major structural lineaments of the Outer Minch Fault and the Moine Thrust (Emeuleus and Bell, 2005; Figure 1).

Sedimentary accumulations on the Isle of Skye were deposited during several rifting episodes prior to the onset of volcanism during the Paleocene (England et al., 1993). Precambrian Lewisian basement outcrops on the Sleat Peninsula and are thought to underlie most of the area. Torridonian (Precambrian) sediments unconformably overly the basement rocks, which are in turn unconformably overlain by Cambro-Ordovician shelf deposits that outcrop on the foreland of the Caledonian orogeny and within the Moine Thrust belt (Trewin, 2002). Prolonged collapse of the Caledonian orogenic belt from the late Devonian through to the Carboniferous allowed for basin development and infilling of Permo-Triassic through to Late Cretaceous sediments within the Sea of the Hebrides (Stein, 1988). The sediments were deposited in a series of west-dipping half grabens controlled by the southwest-northeast-trending Minch and Camasunary Faults (Figure 1).

The onset of volcanism on the Isle of Skye began at approximately $62 \mathrm{Ma}$ (Hamilton et al., 1998) comprising the eruption of lavas and hyaloclastites, as well as the emplacement of sheet intrusions (sills and dikes), followed a few million years later by the emplacement of large-scale intrusive complexes, such as the Black 
and Red Cuillins. For this study, cliff exposures of the base-basalt transition at Neist Point in the far northwest and Camas Ban in the Isle of Skye have been investi- gated. At Neist Point, basalt lavas forming part of the Skye Main Lava Series were unconformably erupted onto a surface comprising mixed Jurassic sediments
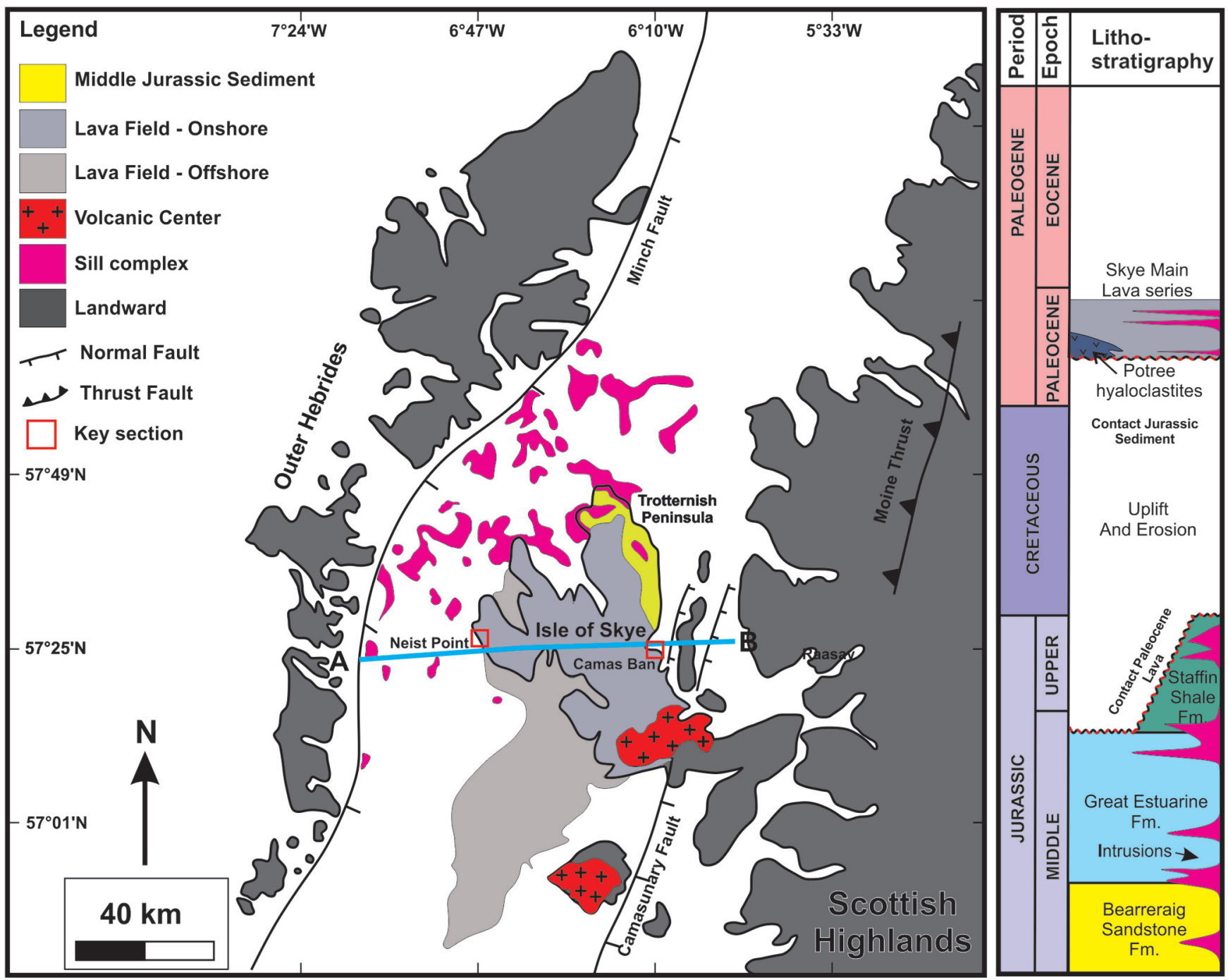

A

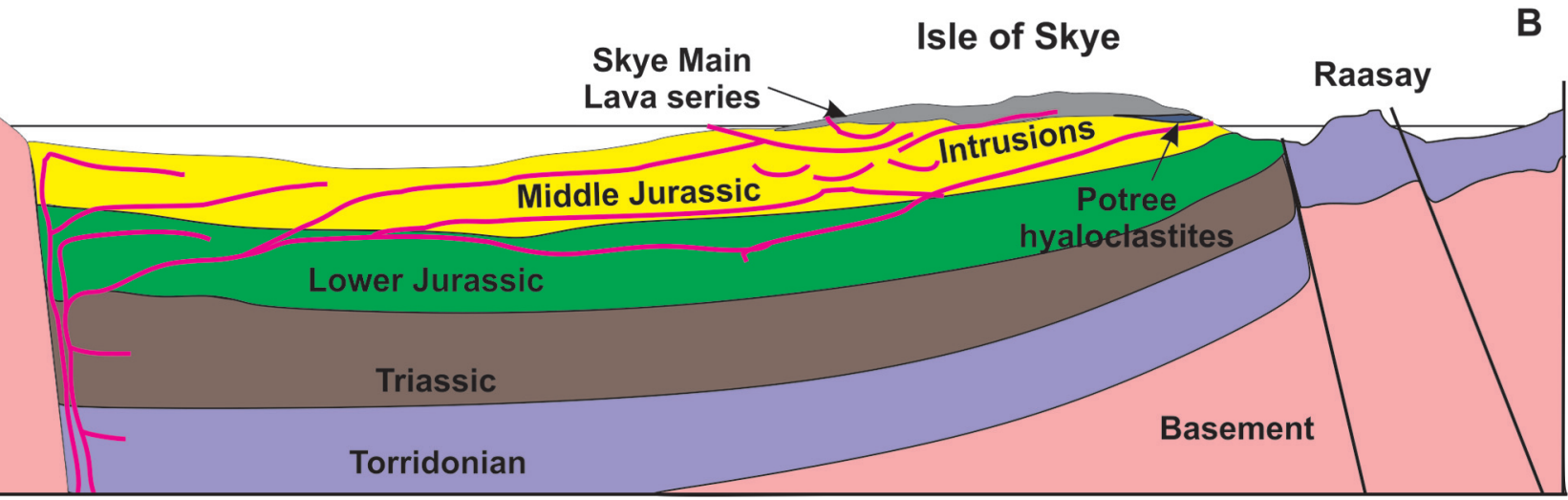

Figure 1. Map showing the regional setting of the Isle of Skye. The lava sequences extend offshore to the southeast, and the sill complex facies are widely distribute offshore. The subaerial base basalt at Neist Point is located in the northwest of Skye, and the Camas Ban hyaloclastites succession is located on the east coast. The stratigraphic section comprises Middle Jurassic sedimentary rocks of the Lealt Shale Formation. Cretaceous rocks are not present within the Neist Point and Camas Ban sections because of uplift and erosion within the study area. Simplified map lithostratigraphy and cross sections modified after Emeleus and Bell (2005) and Schofield et al. (2016). 
of sandstone, limestone, and organic-rich shale. The contact is obscured by approximately $10 \mathrm{~m}$ of dead ground at Neist Point, but the first exposed eruptive deposits comprise subaerial sheet lavas. The sedimentary rocks below the subaerial lavas are dominated by Middle Jurassic shallow marine siliciclastic sediments (Searl, 1994; Morton, 1999; Hesselbo and Coe, 2000) and estuarine strata with many coarse-grained facies, crossbedding sedimentary structures, and nonmarine shales (Morton, 1983; Harris, 1989). The subbasalt sediments have locally been extensively intruded by dolerite sheet intrusions.

At Camas Ban, on the east coast of Skye, the basal contact between the Middle Jurassic Bearreraig Sandstone Formation and the Skye Main Lava Series is obscured by a dolerite sill. In contrast to Neist Point,

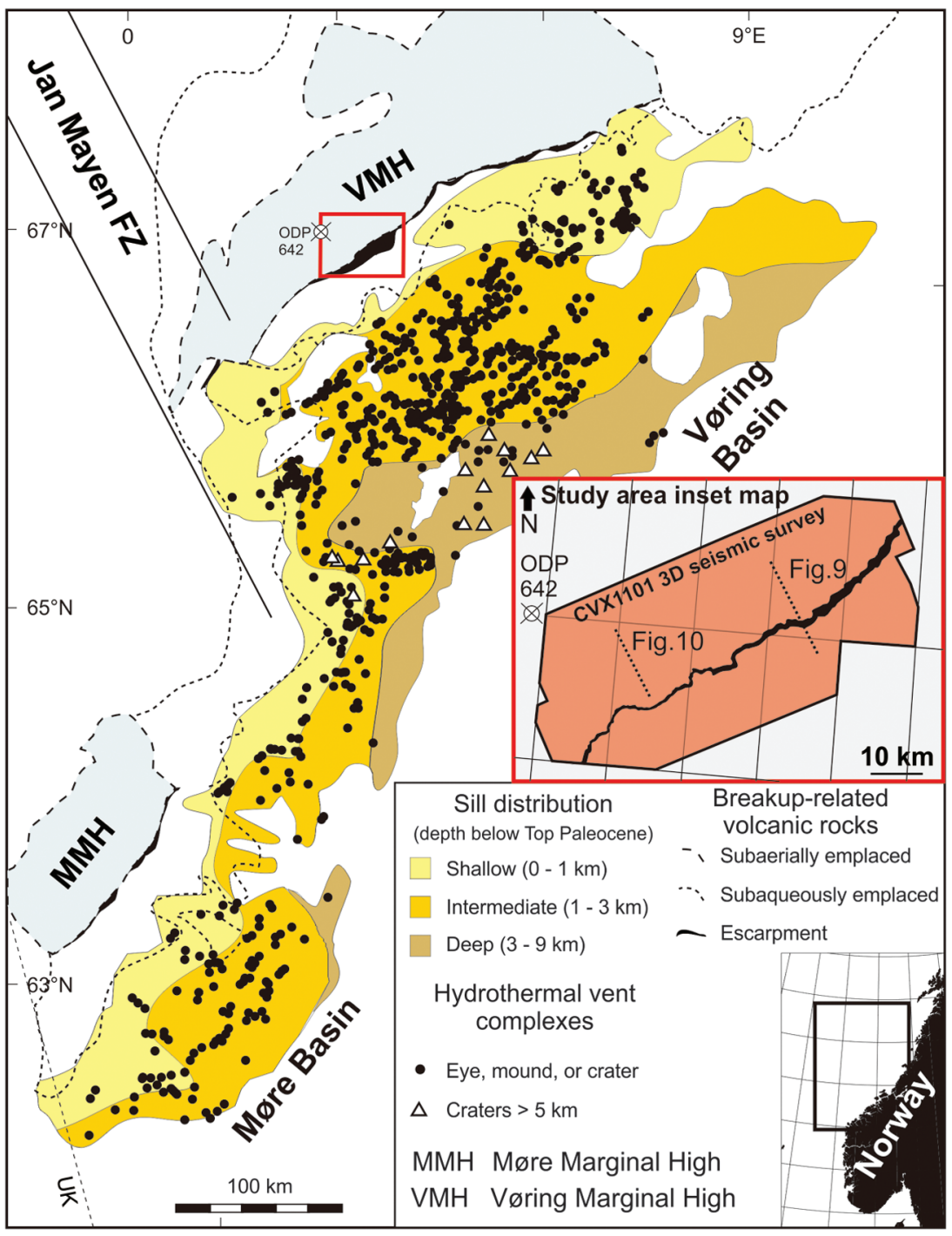

Figure 2. Map showing the distribution and depth of mapped sills and associated hydrothermal vents within the Vøring and Møre Basins, offshore Norway (modified after Svensen et al., 2004). The red square shows the location of the study area (inset) on the VMH and Escarpment, ODP hole 642 for location reference in the map and inset. Note the complete lack of any identified vents beneath the subaerially erupted volcanics. the oldest exposed volcanic succession comprises hyaloclastite breccias, sands, and silts, which are overlain by tabular sheet flows, representing the passage zone to subaqueous emplaced volcanics (Skilling, 2002). Therefore, at Camas Ban, subaqueous conditions prevailed at the onset of volcanism promoting the development of a lava delta.

\section{Offshore: Vøring Basin, Norwegian Margin}

Selected 2D lines from a larger 3D seismic survey (CVX1101, Figure 2) across the Vøring Marginal High (VMH), offshore Norway, were interpreted to compare the onshore study area from the Isle of Skye with a base-basalt sequence from offshore within the NAIP. Additional detailed interpretations of the CVX1101 3D cube are presented by Planke et al. (2017). The Vøring Basin was formed during an extensional tectonic regime in the Middle JurassicEarly Cretaceous (Bjørnseth et al., 1997). Major volcanic activity associated with the NAIP occurred during the Cenozoic resulting in the emplacement of extensive basalt-dominated sequences. However, the age of volcanic rocks within Vøring Basin are thought to be younger, e.g., approximately $56 \mathrm{Ma}$ (Svensen et al., 2010), than those from the Isle of Skye, approximately $62 \mathrm{Ma}$ (Hamilton et al., 1998). Key seismic lines were selected from the $\mathrm{VMH}$, in an area where the lava cover is thin and comprises a sequence of dominantly mid-oceanic ridge basalt-type lavas as identified from Ocean Drilling Project (ODP) Leg 104 Hole 642E (Viereck et al., 1989; Abdelmalak et al., 2016), and termed Landward Flows as a seismic facies (e.g., Planke et al., 2000). The lava sequence predominantly overlies subaqueous, prograding hyaloclastites in places where the volcanism erupted down the escarpment into standing water. The study sections were chosen because they show clear evidence for the base-basalt transition along with evidence for intrusions beneath the lava cover, and because the resolution from the 3D seismic study allows a good imaging of this base-basalt transition (see Planke et al., 2017).

\section{Data and methods Fieldwork}

As part of this study, detailed field mapping and logging were undertaken within the field areas on the Isle of Skye. Lithological transects recording the volcanic facies and their dimensions were undertaken at Neist Point and Camas Ban (Figure 1). Focus was given to vol- 
canic facies and intrafacies (e.g., Jerram, 2002; Single and Jerram, 2004), where lava flow type (compound, simple, ponded etc.) and flow margin features (e.g., rubbly, smooth, vesicle zoning, presence of soils etc.) were recorded. Intrusions were identified based on the presence of chilled upper and lower margins, stratigraphy transgression/cross-cutting relations, and emplacement features, such as broken bridges (e.g., Schofield et al., 2012, 2016).

\section{Petrophysical properties}

Petrophysical measurements including P-wave velocity and porosity were performed on a total of 26 dry core plugs at the University of Aberdeen (Table 1), collected from samples within the field study areas at Neist Point and Camas Ban on the Isle of Skye. These measurements were performed to image the petrophysical responses of the base-basalt transition in the study area. The P-wave velocity was measured using an industry-standard desktop JSR ultrasonic pulser/receiver and an oscillator recorder. The setting of the receiver used a $35 \mathrm{MHz}$ signal, with low- and high-pass filters of 3.00 and $0.0 \mathrm{MHz}$, respectively. The pulser was set up under $900 \mathrm{~V}$ and $100 \mathrm{~Hz}$ pulse repetition frequency (PRF) with energy pulse of $81.0 \mathrm{~mJ}$. The porosity measurement method used the bulk volume of each core plug, which was calculated from the average of 10 repeated high-precision caliper measurements of length and diameter sufficient to calculate the grain volume and porosity (e.g., Farrell et al., 2014). Combining the porosity, bulk volume, and weight of the sample (scale precision to $0.01 \mathrm{~g}$ ), the bulk density and grain density were calculated.

\section{Seismic volcano-stratigraphy mapping}

The main data available for this study are the 3D seismic cube CVX1101 acquired in exploration license PL527 for Chevron (Figure 2; see also Planke et al., 2017). The data were acquired and processed by CGG Veritas. Acquisition was done using two $4980 \mathrm{in}^{3}$ flip-flop air-gun sources, with a $25 \mathrm{~m}$ shot point interval and recorded on twelve $8 \mathrm{~km}$ streamers with $100 \mathrm{~m}$ streamer separation. Processing was completed in 2013, and time and depth cubes were available for this study. The cube covers $2500 \mathrm{~km}^{2}$, with a $25 \times 12.5 \mathrm{~m}$ inline and crossline bin size. The data were released after the license was relinquished in 2015.

The extrusive rocks were interpreted by seismic volcano-stratigraphic analysis (Planke et al., 2000; Berndt et al., 2001). The subaerial sequences (Land- ward Flows) are characterized by high-amplitude parallel continuous reflections, whereas the subaqueous lava delta facies sequences are characterized by mediumlow amplitude reflection with well-imaged delta foresets (e.g., Jerram et al., 2009; Wright et al., 2012). The inner flows facies domain are characterized by more chaotic mixed high- to low-amplitude reflectors indicative of the dynamic, partly intruded nature of the prodelta deposits (e.g., Planke et al., 2000).

The intrusive igneous units and associated HVCs were interpreted based on the approach of Planke et al. (2015). The intrusive bodies in the seismic reflection data are displayed by high amplitudes and typical "saucer-shaped" morphologies. It is important to note that the amplitudes of the intrusive facies are the brightest reflectors within the subbasalt domain; however, the peak amplitudes of intrusive facies that occur beneath the extrusive volcanic sequence are clearly reduced, due to energy loss through the volcanics, compared with similar scale intrusions not covered by extrusive volcanics. The associated HVCs are characterized by

Table 1. Summary of petrophysical measurements from 26 dry core plugs used to produce the pseudo wireline log for the Neist Point and Camas Ban sections (see Figure $8 b$ and $8 c$ ).

\begin{tabular}{|c|c|c|c|c|c|}
\hline Samples & Location & Volcanic facies & $\begin{array}{c}V_{\mathrm{P}} \\
\text { velocity } \\
(\mathrm{km} / \mathrm{s})\end{array}$ & $\begin{array}{c}\text { Porosity } \\
(\%)\end{array}$ & $\begin{array}{c}\text { Bulk } \\
\text { Density } \\
\left(\mathrm{g} / \mathrm{cm}^{3}\right)\end{array}$ \\
\hline 0205A & \multirow{11}{*}{$\begin{array}{c}\text { Camas } \\
\text { Ban }\end{array}$} & \multirow{3}{*}{$\begin{array}{c}\text { Massive - partly pillow } \\
\text { basalt }\end{array}$} & 5.75 & 0.79 & 2.84 \\
\hline 0205B & & & 5.83 & 0.35 & 2.85 \\
\hline $0205 \mathrm{E}$ & & & 5.45 & 0.09 & 2.84 \\
\hline 0206A & & \multirow{4}{*}{$\begin{array}{c}\text { Massive hyaloclastite } \\
\text { breccia }\end{array}$} & 3.09 & 2.11 & 2.44 \\
\hline 0206B & & & 3.18 & 2.51 & 2.46 \\
\hline 0206C & & & 2.87 & 2.41 & 2.39 \\
\hline $0206 \mathrm{~F}$ & & & 3.68 & 2.85 & 2.47 \\
\hline 0207A & & \multirow[t]{4}{*}{ Weakly bedded hyaloclastite } & 2.32 & 2.17 & 2.27 \\
\hline 0207B & & & 2.28 & 2.06 & 2.27 \\
\hline 0207C & & & 1.97 & 2.09 & 2.27 \\
\hline $0208 \mathrm{~F}$ & & & 2.03 & 2.25 & 2.49 \\
\hline 0603A & \multirow{14}{*}{$\begin{array}{l}\text { Neist } \\
\text { Point }\end{array}$} & \multirow[t]{3}{*}{ Dolerite } & 5.12 & 1.11 & 2.72 \\
\hline 0603B & & & 4.8 & 1.4 & 2.71 \\
\hline 0603E & & & 4.78 & 1.18 & 2.71 \\
\hline $0604 \mathrm{~A}$ & & Limestone (contact) & 5.13 & 1.18 & 2.54 \\
\hline 0605A & & \multirow[t]{2}{*}{ Sandstone } & 2.1 & 21.32 & 2.01 \\
\hline 0605B & & & 2.21 & 17.37 & 2.09 \\
\hline 0606D & & Limestone laminated & 2.48 & 12.34 & 2.16 \\
\hline 0607A & & \multirow[t]{4}{*}{ Tabular lava flow facies } & 5.73 & 2.3 & 2.8 \\
\hline 0607B & & & 5.71 & 1.86 & 2.82 \\
\hline 0607C & & & 5.78 & 1.07 & 2.84 \\
\hline $0607 \mathrm{E}$ & & & 5.64 & 1.01 & 2.84 \\
\hline 0608A & & \multirow[t]{3}{*}{ Compound lava flow facies } & 4.38 & 1.99 & 2.69 \\
\hline 0608B & & & 5.04 & 1.52 & 2.74 \\
\hline $0608 \mathrm{C}$ & & & 4.69 & 2.01 & 2.72 \\
\hline
\end{tabular}


low-amplitude and disturbed seismic reflections emanating from the tips of the interpreted saucer-shaped intrusion. Care was taken to highlight examples in which no faulting intersects the proposed vent examples, and therefore a faulting origin of the disturbed reflectors can be discounted.

\section{Results}

\section{Field observations: Isle of Skye}

The main study area (Neist Point) is located on the Durinish Peninsula, in the northwest of the Isle of Skye (Figure 3a). The topographic elevation range is approximately from 0 to $300 \mathrm{~m}$, and the section length is more than a kilometer, providing a large outcrop area, comparable with seismic-scale outcrop observations (Figure 4a). The section presents a seismic-scale onshore analogue of a subaerial base-basalt transition, with significant associated intrusive activity forming the focus of the onshore study (Figure 4b). A smaller scale (100 m in length

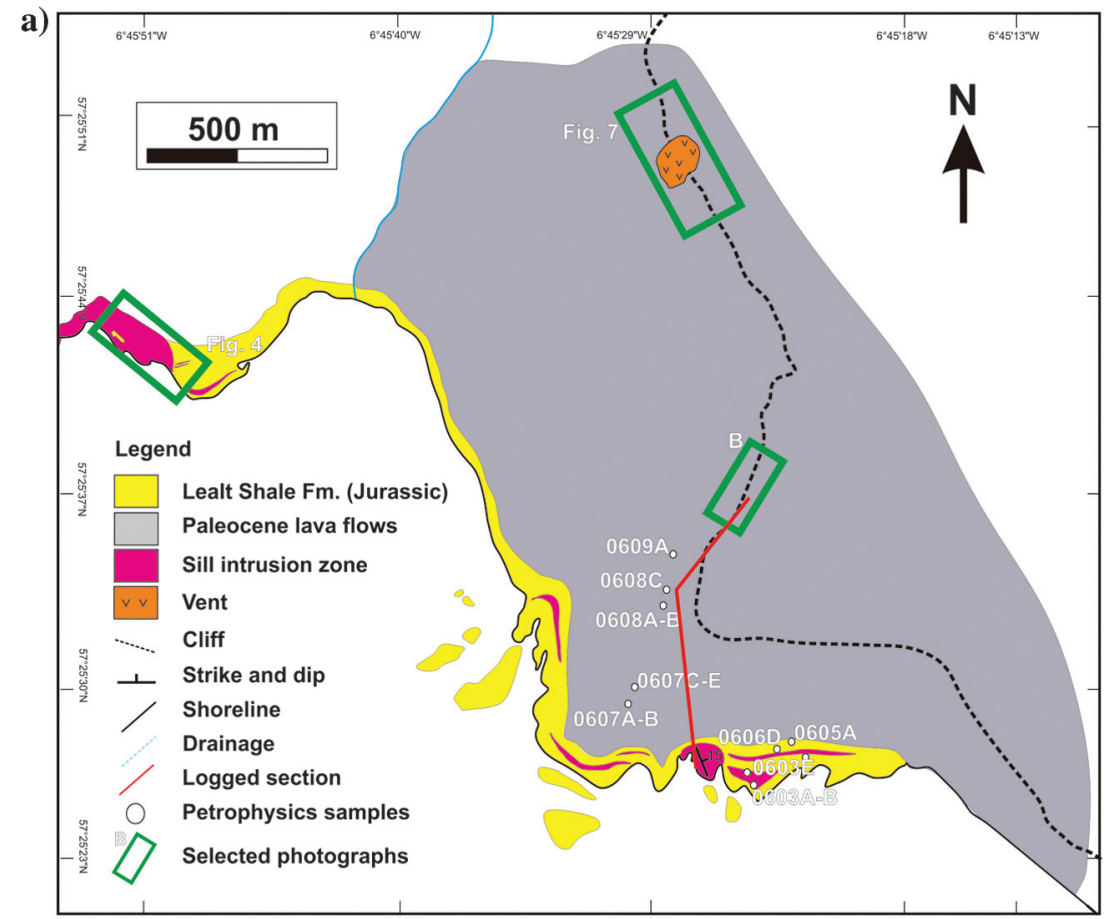

b)

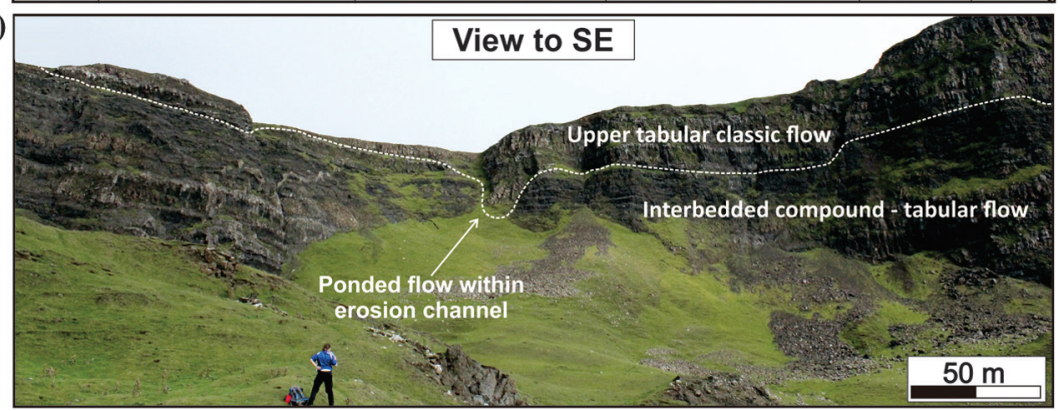

Figure 3. (a) Simplified geologic map of Neist Point, Isle of Skye, displaying sample locations and the logged transect. (b) Field photo showing the main lava flow facies above the base-basalt transition at Neist Point. Note the evidence for eruption hiatuses where deep erosional channels have been incised and subsequently filled by ponded flows. and $35 \mathrm{~m}$ in height) study of hyaloclastite facies at Camas Ban (Figure 5a) on the east coast was undertaken to compare the velocity variations at the base-basalt transition where hyaloclastites form the initial deposits.

\section{Base-basalt transition}

The base-basalt transition at Neist Point is characterized by an apparently sharp unconformable transition from Jurassic sedimentary rock into a >200 m thickness of subaerial flood basalts (Figure 3b). The absence of hyaloclatites at the Neist Point transition suggests a subaerial environment at the onset of flood volcanism at this location, although a short interval of nonexposure (approximately $10 \mathrm{~m}$ ) means that the presence of minor water interaction cannot be entirely excluded. The lava sequence is composed of interbedded compound braided and tabular classic flow facies indicative of low- and high-bulk-volume lava eruptions, respectively (e.g., Jerram, 2002; Single and Jerram, 2004).

The main phase of flood volcanism is marked by an upper tabular lava flow sequence comprising several stacked individual lava flows ( $>10 \mathrm{~m}$ in thickness, Figure 3b). Hiatuses between lava eruptions are inferred by the preservation of approximately 1-1.5 m thick, reddened paleosols. Evidence for prolonged intereruption hiatuses (e.g., Jolley et al., 2012) within the main tabular sequence is also recognized from the presence of deep erosional channels cut down (approximately $20 \mathrm{~m}$ ) into the underlying flows, which have subsequently been filled by ponding of later lavas and require enough time to develop erosional drainage systems on the lava surface (e.g., Schofield and Jolley, 2013; Ebinghaus et al., 2014). The lava pile at Neist Point therefore presents a complex and typically heterogeneous lava sequence (Figure 3b), which would cause significant scattering and attenuation of seismic energy, and therefore create imaging challenges in the subsurface (e.g., Gallagher and Dromgoole, 2007; Davison et al., 2010).

The lava sequence at Camas Ban comprises a roughly similar range and heterogeneity to that observed at Neist Point with one key difference: The lower $>30 \mathrm{~m}$ of the volcanic succession comprises mixed hyaloclastite facies emplaced into standing water (Figure 5b). Outcrops of weakly bedded to massive hyaloclastite facies (Figure $5 \mathrm{c}$ and $5 \mathrm{~d}$ ) are replaced upward by lavas with evidence for downslope migration of large lava lobes (lobes steeply inclined relative to the dip of the overlying lava sequence), a feature typical of high effusion 
rates at lava delta passage zones (e.g., Skilling, 2002). The physical properties of the hyaloclastites are distinctly different from the lavas (Figure 3), with the hyaloclastites displaying much lower and more consistent $\mathrm{P}$ wave velocities ranging from 1.97 to $3.18 \mathrm{~km} / \mathrm{s}$, consistent with other studies from the NAIP (e.g., Nelson et al., 2009). The base-basalt transitions at Neist Point and Camas Ban are, therefore, demonstrated to be distinctly different in terms of their volcanic facies, but also in terms of their velocity structures as a consequence of the presence or lack of water during the onset of volcanism at each location. This simple observation, backed by new petrophysical results from laterally equivalent outcrops (similar age, burial etc.) in the same province, provides a firm basis for future characterization of heterogeneities in physical properties at the basalt-sediment transition. This has important implications for the way in which we attempt to interpret the base-basalt transition from remote seismic data because, as our data demonstrate, the transition may be distinctly different in terms of velocity and density depending on the volcanic facies, which should be taken into account when interpreting seismic data. Studies of other base-basalt transition sections in LIPs increasingly highlight that hyaloclastites can commonly be found (e.g., Pedersen et al., 1998; Jerram et al., 2016a, 2016b), and their occurrence and distribution is being recognised and mapped in offshore sections (Jerram et al., 2009; Wright et al., 2012; Abdelmalak et al., 2016).

\section{Dolerite intrusion}

A variety of intrusive morphologies are observed at Neist Point ranging from thin discordant sheets cutting the entire exposure to sill intrusions, which are a few $\mathrm{cm}$ to tens of meters thick (Figure 6). Complexity ranges from simple sheet intrusions to interconnected, stacked sill complexes. Sill intrusions, although not absent from the lava pile, primarily occur within the underlying Jurassic sedimentary rocks, and, in places, they comprise more than $50 \%$ of the rock volume within the upper few tens of meters of the subbasalt stratigraphy. Features preserved within the dolerite intrusions below the base-basalt transition include intrusion steps and broken bridge structures (Figures 4 and 6; e.g., Thomson and Hutton, 2004; Hutton, 2009; Schofield et al., 2012, 2016).

The emplacement of sill intrusions may deform or jack up surrounding sedimentary rocks forming forced folds, which have been clearly defined from field observation (e.g., Pollard and John-

a)

b)

c) had cooled. son, 1973) and imaged in seismic data (e.g., Hansen and Cartwrigth, 2006; Jackson et al., 2013; Magee et al., 2013). Evidence for forced folding at Neist Point is clearly recorded within the Jurassic strata surrounding the sill tip, where the sill abruptly thins from a thickness of $>30 \mathrm{~m}$ and dips beneath sea level (Figure $4 \mathrm{~b}$ ). The overlying sedimentary layers clearly follow the upper margin of the sill tip, which is inclined (approximately $20^{\circ}$ dipping to the northwest) in comparison with the subparallel bedding within the Jurassic sedimentary rocks beyond the tip of the sill. This clearly indicates that they were displaced upward to accommodate the sill volume as opposed to being replaced or folded prior to intrusion. Numerous small inclined intrusive sheets emanate from the sill tip and cut through the sedimentary rocks folded around the sill tip (Figure 4d; e.g., Thomson and Schofield, 2008; Magee et al., 2016). The presence of chilled contacts between some of these sheets and the larger sill body suggests that additional magma charges occurred, subsequent to the main inflation stage of the large sill occurred (Figure $4 \mathrm{~d}$ ).
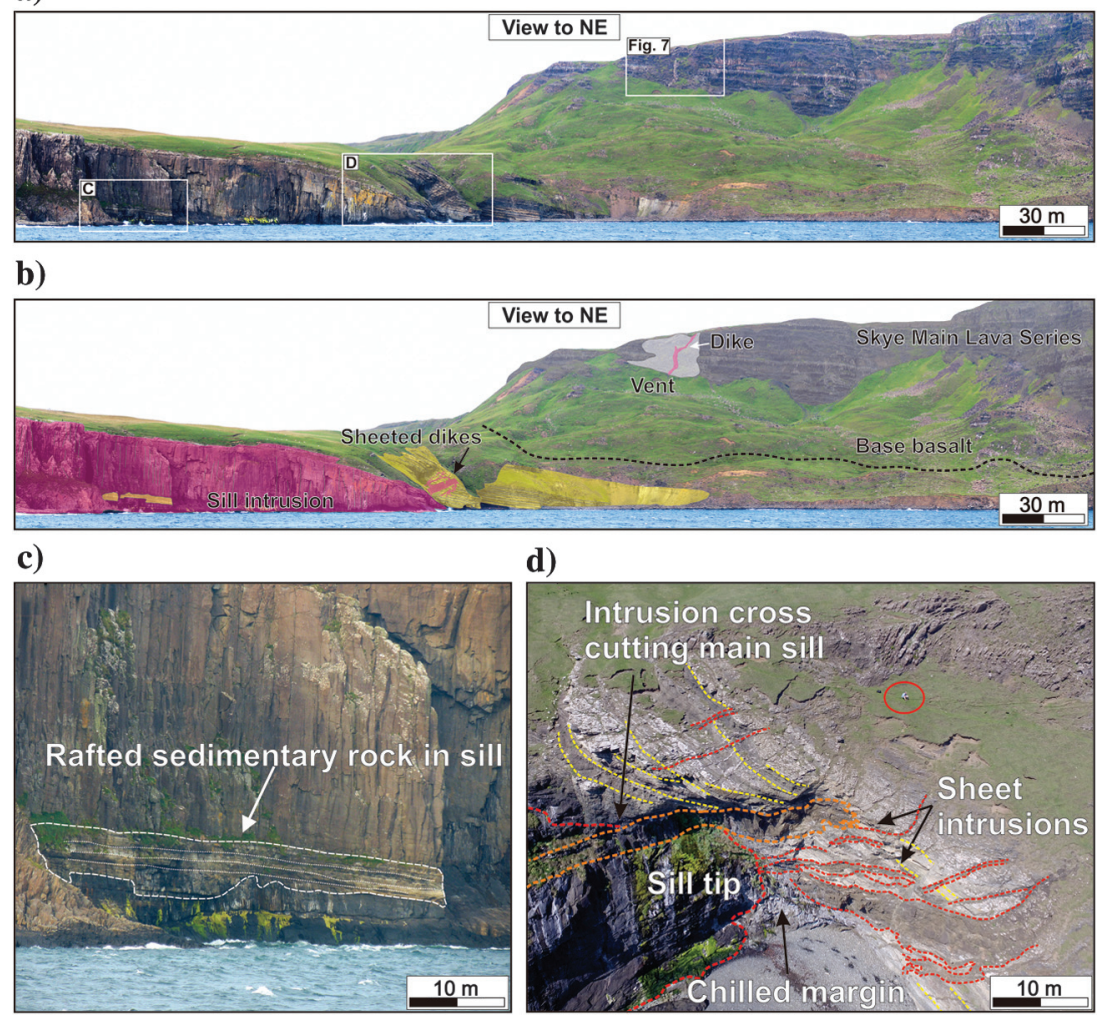

d)

Figure 4. (a) Photograph showing the studied section at Neist Point, Isle of Skye. (b) Interpretation showing the large sill and upward displacement of the intruded Jurassic host sediments. Above the sill tip, a chaotic vent breccia (see Figure 7) is observed cutting through the lava pile. An irregular dike was subsequently fed up through the weakness caused by the vent pipe breccia, potentially linked to renewed injection of magma from the same system that fed the larger initial sill. (c) Isolated sediment rafts are observed within the core of the large sill intrusion. (d) Detailed features of the forced fold and sill tip displaying numerous thin inclined sheet intrusions emanating from the main sill and cutting through the deformed sedimentary layers. Note the later sheet intrusion cutting the main sill, which is evidence for the later magmatic pulse after the initial sill 


\section{Hydrothermal vent}

In the current research of flood-basalt volcanism, the occurrences of onshore examples for hydrothermal vents mostly occur exposed within sedimentary formations (e.g., Svensen et al., 2004, 2006). Extensive vent complexes are known from the subbasalt sedimentary sequences in, e.g., the Karoo LIP and the Siberian Traps,

a)

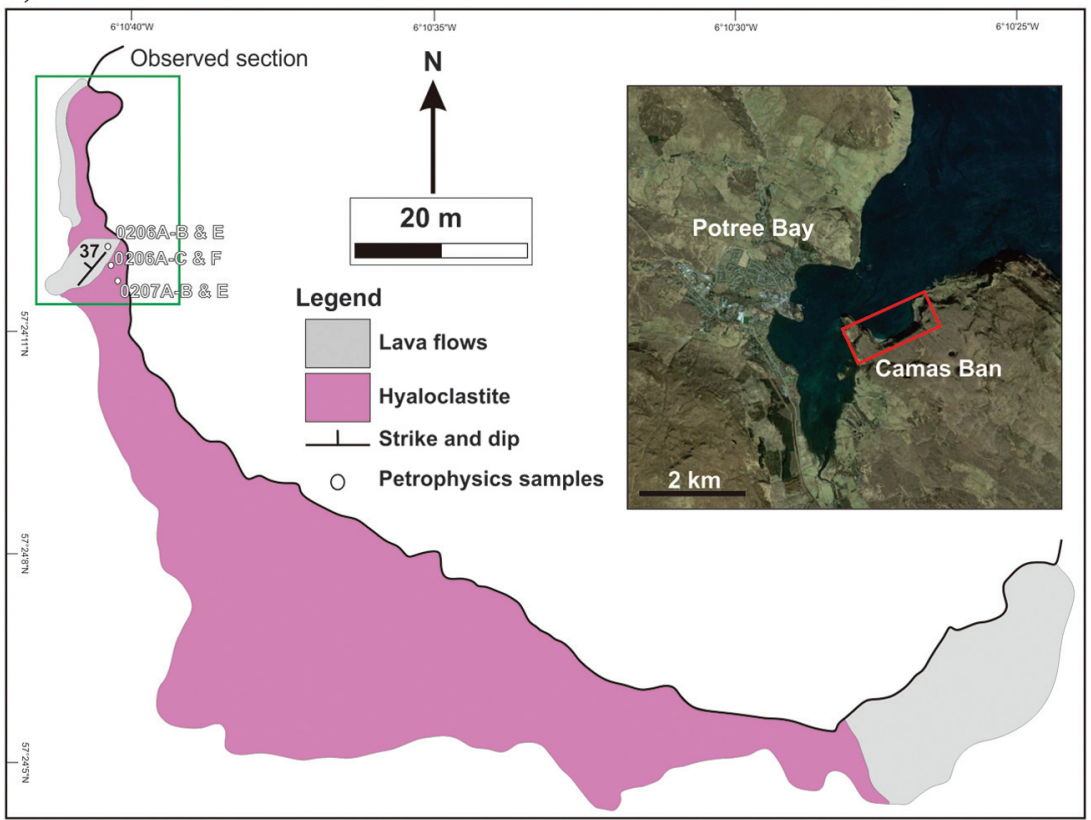

b)

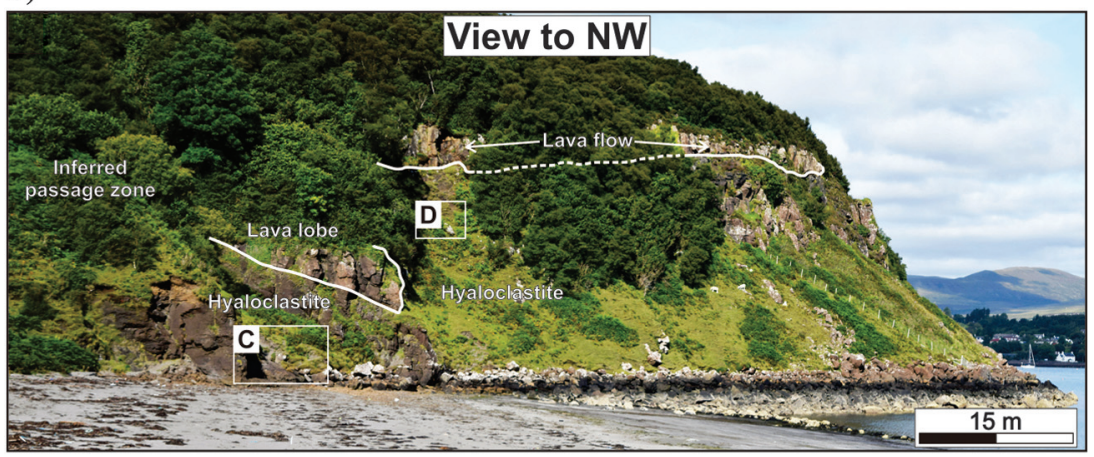

c)

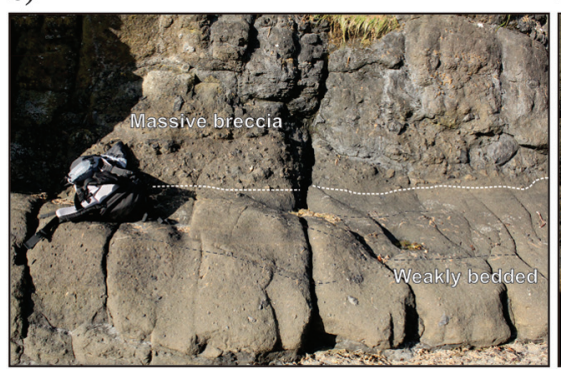

d)

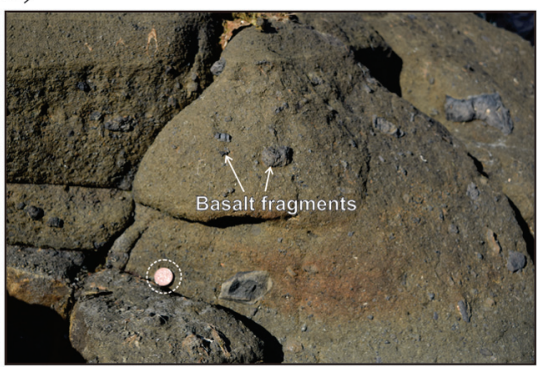

Figure 5. (a) Simplified map of the Camas Ban section, Isle of Skye, showing petrophysical sample locations. (b) Hyaloclastite delta facies at the subaqueous to subaerial passage zone. (c) Internal structure displaying a weakly bedded unit overlain by more chaotic hyaloclastite breccia. (d) Detail of the poorly sorted hyaloclastite breccia, including angular blocky to the irregular basalt fragments and altered glassy matrix. but rarely are the associations between the intrusion and the vent structures cutting overlying lavas observed together in coordination. In the Neist Point section, we oxerve the first example to our knowledge of this set, where the intrusion and an associated vent are obcutting through the overlying basalt sequence (Figure 4b). Due to the exposure at Neist Point, there is a lateral offset of a few hundred meters between the exposure of the large sill and the exposure (stepped back from the shoreline) of the vent conduit. The apparent offset in Figure $4 \mathrm{~b}$ is therefore simply an artifact of the position at which the photograph can be taken from, e.g., the lighthouse peninsula at Neist Point. Our interpretation (informed by numerous seismic examples), and without contrary evidence, is that the sill continues inland beneath the lava pile as a simple sheet intrusion, which would place the sill margin directly below the base of the vent structure $<100 \mathrm{~m}$ below the current vent exposure.

The vent structure (Figure 7a) is composed of subangular to subrounded clasts of the host rock (basalt lava) ranging from a few tens of cm up to approximately $2 \mathrm{~m}$ in diameter, with oxidized brecciated volcanic material as the matrix (Figure 7b). At least some of the rounding of the basalt clasts appears to be the result of pervasive postemplacement alteration, evidenced by the deeply altered rims of many of the clasts (Figure 7c). The presence of large amygdales and vesicle layers within clasts, which display no spatial association to the geometry of the clasts (e.g., no concentric arrangements), precludes a primary origin of the clasts (e.g., pillows). The breccia is very chaotic and poorly sorted with no evidence for internal structuring. The irregular contacts between the breccia and the host lava flows differ significantly from the smooth erosional channel features identified elsewhere in the sequence (Figure 7a), which, along with the lack of any internal bedding features, argues against an erosion and infill origin for the breccia.

The 2D surface exposure of this vent and the fact that the breccia pipe conduit is preserved prevents comment on its 3D geometry as well as its crater type (e.g., circular; narrow features or dome, crater, and eye-type of Planke et al., 2005). The exposed width of the vent conduit is approximately $20 \mathrm{~m}$ in diameter. Within the central part of the 
vent conduit, an irregular dike of 1-2 $\mathrm{m}$ in thickness is present (Figure 7a). It is unclear, without the addition of chemical analysis, whether the dike has the same composition as the underlying sill intrusion. There is evidence for at least two magma pulses associated with the intrusion tip (Schofield et al., 2015), and therefore it is possible that after the initial intrusion, incubation, and vent formation, a second pulse of magma along the same pathway intruded up the newly developed area of weakness formed by the vent.

\section{Petrophysical variations of the base-basalt transition: Isle of Skye}

Coherent and dense rock samples (lavas and intrusions) display the highest values of P-wave velocity and density $\left(5.8-4.3 \mathrm{~km} / \mathrm{s}\right.$ and $\left.2.69-2.89 \mathrm{~g} / \mathrm{cm}^{3}\right)$, and the lowest values of porosity $(0.02 \%-2.79 \%)$ within the data set due to their tightly bound interlocking crystals. The P-wave velocities for hyaloclastites sampled at Camas Ban range from 1.9 to $3.6 \mathrm{~km} / \mathrm{s}$, with porosities from $2.0 \%$ to $26 \%$ and density ranging from 2.27 to $2.47 \mathrm{~g} / \mathrm{cm}^{3}$. Petrophysical properties of sedimentary rocks at Neist Point (e.g., sandstone and limestone) were also sampled at varying distances from intrusions. The P-wave velocities for sandstone at $30 \mathrm{~cm}$ from contact range from 2.4 to $3.3 \mathrm{~km} / \mathrm{s}$ with porosity values of $6.2 \%-12 \%$, whereas sandstones at the contact show $2.15-2.75 \mathrm{~km} / \mathrm{s}$ and $16.5 \%-26.2 \%$, respectively. Moreover, the limestones sampled at the intrusion contact present low values of porosity $(0.9 \%-2.0 \%)$ and high values of P-wave velocities $(5.0-5.2 \mathrm{~km} / \mathrm{s})$ similar to the dolerite samples. A broad relationship of increasing $\mathrm{P}$-wave velocities and decreasing porosity of sediments toward the dolerite contact is seen (Figure 8a), which are indicative of the thermal aureole caused by contact metamorphism altering the velocity structure of intruded sediment host rocks.

To represent the distribution of volcanic facies identified on Skye in terms of geophysical responses (Figure 8b), pseudo wireline logs for P-wave velocity, porosity, and density were compiled for the Neist Point and Camas Ban sections (Figure 8c). The logs were constructed using the petrophysical measurements of volcanic rocks and sediments to give a representation of the variation that may be expected from wireline data through the separate sections. Detailed geologic observations, including the thickness of the flow structure in lava flows (core versus crust) and the distribution of basalt clasts in hyaloclastite facies, from the logged sections are used as a guideline to demonstrate the potential variations through the separate sequences. Wireline-log profiles through basalt flows (e.g., an asymmetrical bell shaped curve; Planke, 1994; Nelson et al., 2009) and those seen through hyaloclastites successions (e.g., Nelson et al., 2009; Watton et al., 2014) have also been incorporated to help conceptually populate the pseudologs away from the constrained measurements from this study (e.g., Single and Jerram, 2004).

\section{Offshore seismic examples: $\mathrm{VMH}$}

The seismic volcano-stratigraphy across the VMH displays a classic volcanic rifted margin succession. In the current study, identified facies include (1) Landward Flows, (2) Lava Delta, and (3) Inner Flows (e.g., Planke and Alvestad, 1999; Planke et al., 2000; Abdelmalak et al., 2016). Detailed mapping of the basalt sequences in the CVX1101 3D cube (Planke et al., 2017) allows the location of lines where the volcanic cover is thin, and therefore the subbasalt image resolution is best. The preserved Landward Flow thicknesses are around $500 \mathrm{~m}$ or less in the two example seismic lines chosen (Figures 9 and 10). In Figure 9, a prograding Lava Delta sequence is clearly imaged displaying a subaqueous to subaerial passage zone similar to those seen in other parts of the NAIP (e.g., Pedersen et al., 1998; Watton et al., 2013; Millett et al., 2015). Beneath the interpreted base-basalt transition, a clear saucer-shaped intrusion is imaged and appears to have locally jacked up the

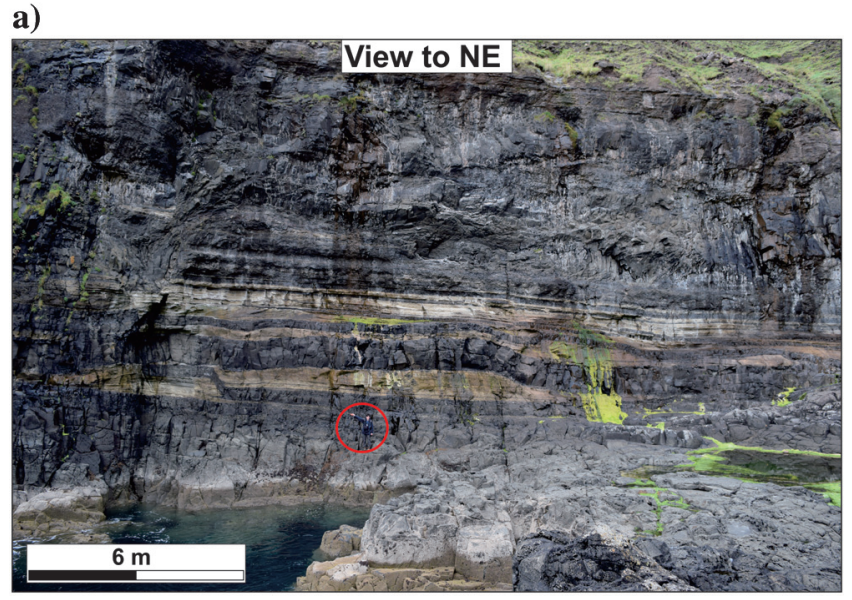

b)

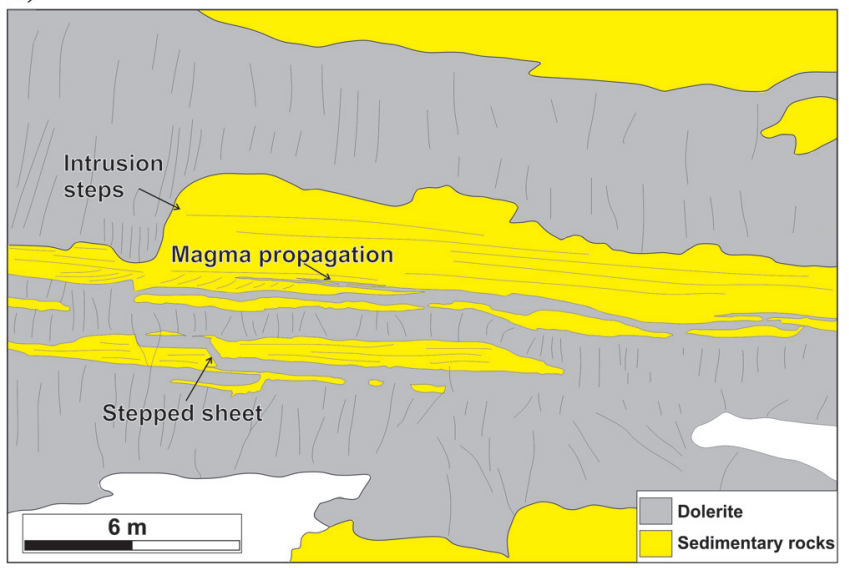

Figure 6. (a) Photograph showing the intruded basal section below the Skye Main Lava Series at Neist Point. (b) Interpreted section displaying key intrusive emplacement features. The sills were intruded in a mixed clastic sedimentary succession of the Jurassic Lealt Shale Formation. with individual sheets having a range of thicknesses ranging approximately from 0.2 to $10 \mathrm{~m}$ (in this section) and comprising $>50 \%$ of the presentday rock volume in the first few tens of meters below the basalt-sediment transition. 
immediately overlying sediments of the base-basalt surface and formed a forced fold spanning approximately $300 \mathrm{~m}$ across. The amplitude of the forced-fold structure appears to diminish upward into the volcanic sequence from approximately $100 \mathrm{~m}$ at the base-basalt level down to approximately $0 \mathrm{~m}$ at the hyaloclastite to lava transition, an interval of approximately $500 \mathrm{~m}$. It therefore appears to represent a shallow intrusion, emplaced prior to or during the overlying lava delta development, potentially also promoting differential compaction during rapid emplacement of the high-density volcanic overburden.

In Figure 10, a large high-amplitude saucer-shaped intrusion (Sørenssen et al., 2004; Planke et al., 2005) is clearly observed beneath the base of the high-amplitude flat-lying Landward Flows. Vertical zones of disrupted reflectors are observed emanating from the tip of the high-amplitude sill reflectors and cutting up through the volcanic pile. The pipe-like features show no offset of the host stratigraphy (e.g., sedimentary rocks and Landward Flows) and, thus, they do not appear to be associated with faults. We interpret these features as HVCs with a maximum vertical extent of approximately $1.3 \mathrm{~km}$ above the sill tip termination and a width of less than approximately $450 \mathrm{~m}$. A clear crater-type morphology is not observed, but the overlying lava strata are clearly domed above the underlying disrupted strata (e.g., Planke et al., 2005).

\section{Discussion Variability of the base-basalt transition within the NAIP}

The onset of volcanism at the base-basalt transition may in simple terms occur either onto land (subaerial)

a)

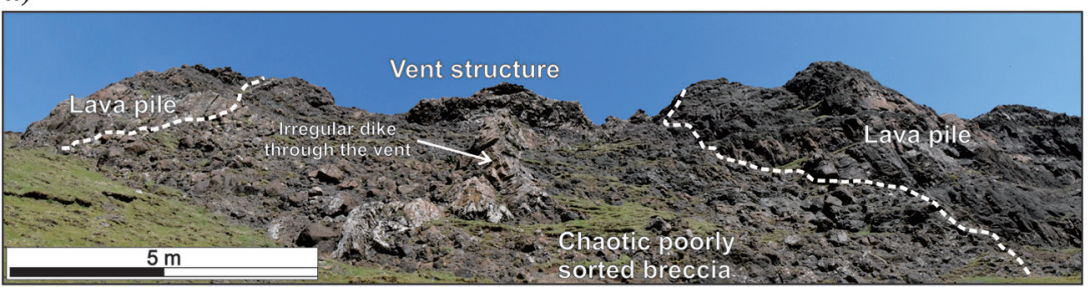

b)

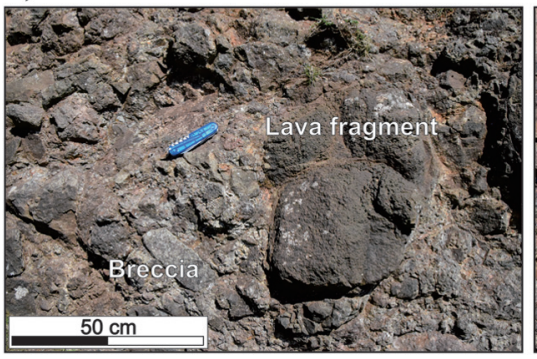

c)

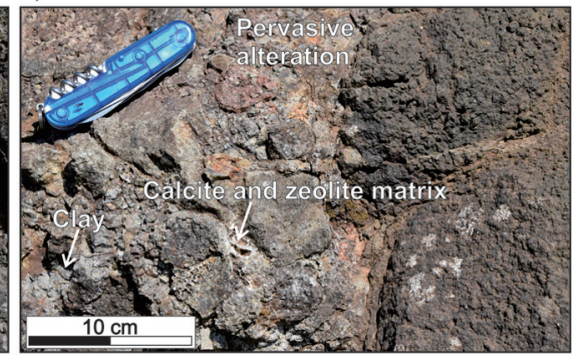

Figure 7. (a) Photograph showing the vent breccia cutting up through the lava pile ( $>10 \mathrm{~m}$ in width), with an irregular dike (approximately 1-2 $\mathrm{m}$ in thickness) intruding the vent core at a later stage. (b) The vent is composed of subrounded to subangular clasts of the host lava with altered and oxidized matrix. (c) The clastsupported vent breccia shows evidence of extensive alteration and hydrothermal mineralization due to the presence of calcite, zeolite, and clays within the matrix. or into water (subaqueous). Neist Point on the Isle of Skye displays a subaerial example, where the initial volcanism produced compound (low volume) and tabular (high volume) lava flow facies, occasionally interdigitated with reddened paleosols (e.g., Jolley et al., 2012). In other areas, such as at Camas Ban, subaqueous conditions were initially present, suggestive of a variable topography on Skye at the time. The pseudo wireline logs generated from the onshore Skye examples clearly demonstrate the large difference in velocity contrast between a subaqueous compared with subaerial eruptive ansition. However, the presence of intrusions into the basalt sediments significantly complicates the wiree profiles and may significantly reduce the sharpness the transition at the resolution of common seismic reflion surveys. The identification of characteristic intruse signatures (e.g., Planke et al., 2005, 2015) at the the nature and the location of the

In the offshore domain, hyaloclastites can often be found indicating that eruption into water at the onset of flood volcanism was widespread across the NAIP margins (Jerram et al., 2009; Wright et al., 2012; Abdelmalak et al., 2016). The studied examples from the offshore Vøring Basin clearly display subaerial and subaqueous base-basalt transitions relating to the topographic varlations across the VMH (Abdelmalak et al., 2016). Simlar to the onshore examples from this study, intrusions re clearly identified in close association to the interbasalt-sediment transition, especially in the Inner Flows domain. Our study forms an initial step toward better characterization and understanding of variations in the volcanic facies and physical properties of the base-basalt transition in different settings. Future integrations of detailed onshore examples are critical steps for improving the imaging, identification, and characterization of the basebasalt transition in offshore sequences, especially where a thick basalt cover exists (e.g., Millett et al., 2015).

\section{Magma emplacement and host rock deformation}

Extensive dolerite intrusions were emplaced into the sedimentary sequences beneath the extrusive volcanic sequences in the onshore and offshore study areas. In both cases, examples of the host sediments being deformed upward to accommodate the intrusions and forming "forced-fold" structures have been identified (Figures $4 \mathrm{c}$ and 11b). A range of morphologies within the onshore Neist Point sheet intrusions are identified, including sediment bridges, broken bridges, intrusion steps, and sediment rafts (e.g., Schofield et al., 2016), which 

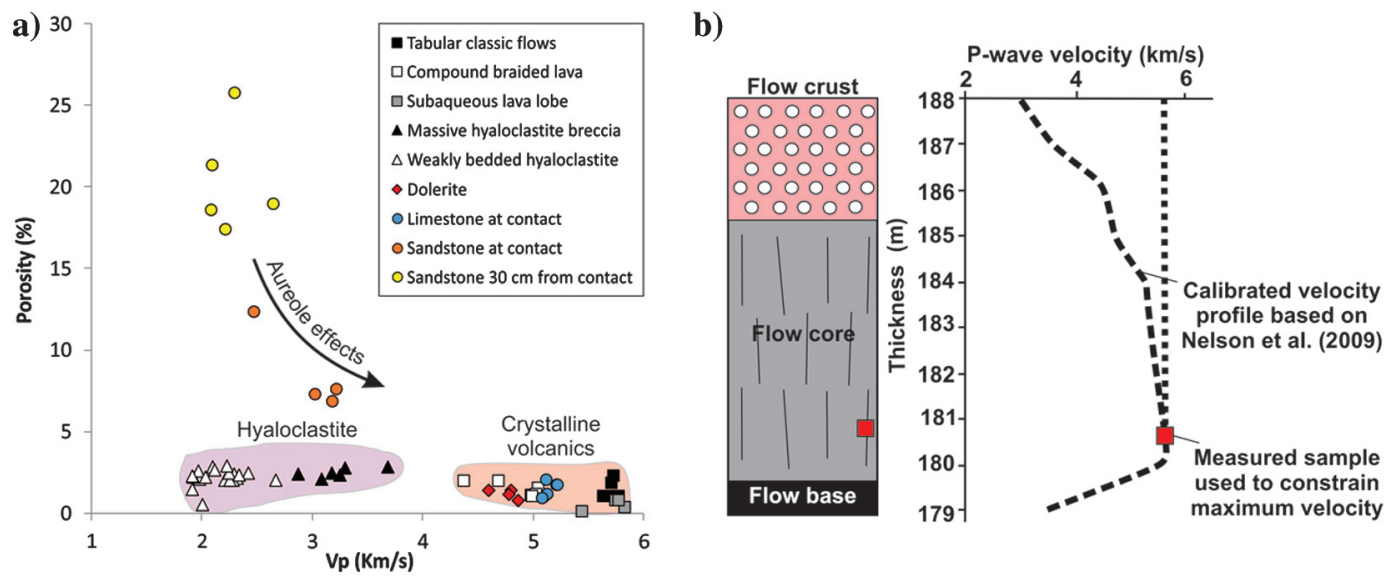

c)

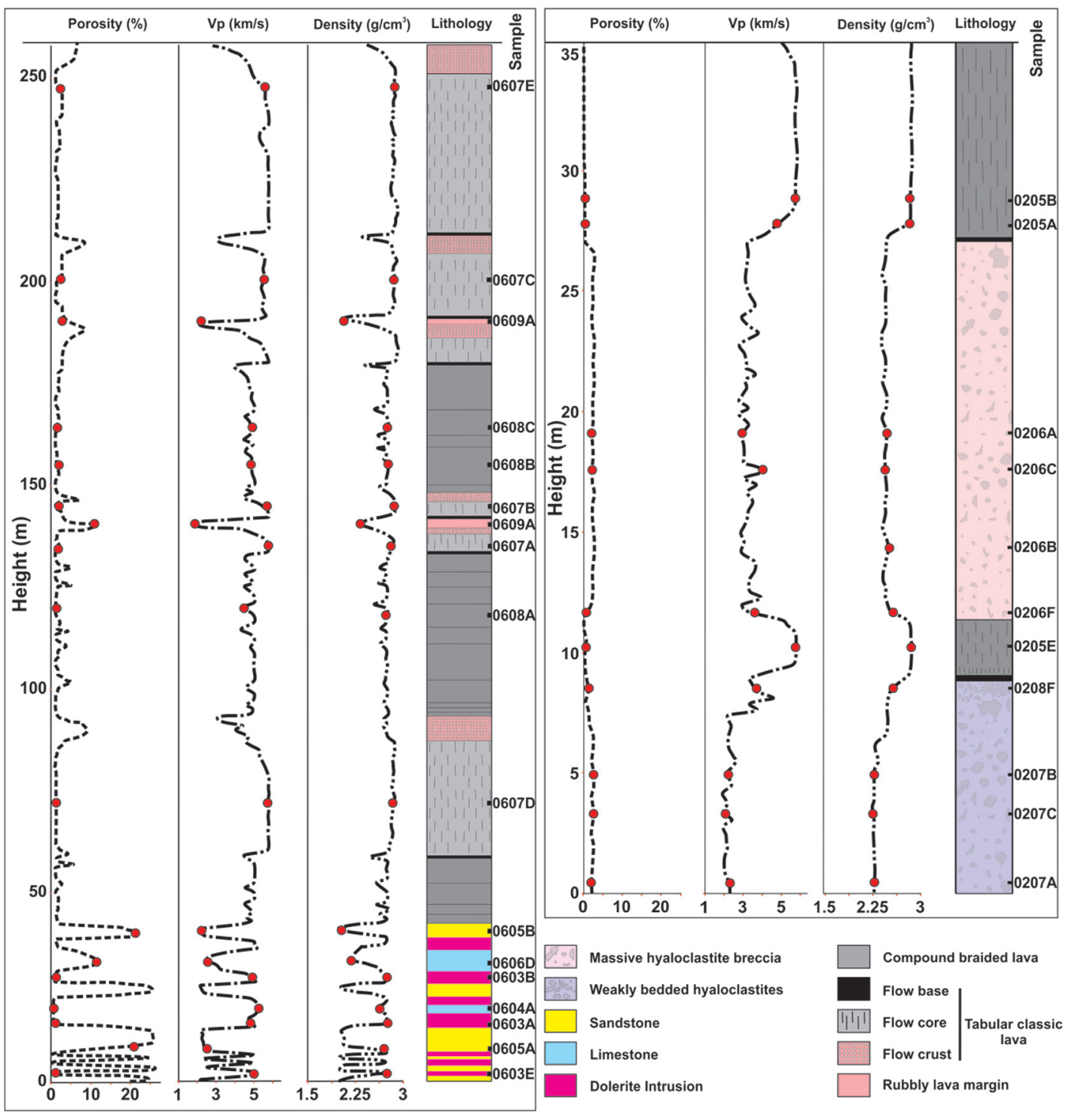

Figure 8. (a) Schematic diagram of lava flow pseudolog using measured sample (flow core) as maximum values. The bell-shaped velocity profile through the lavas is calibrated using published examples from borehole data (e.g., Planke, 1994; Single and Jerram, 2004; Nelson et al., 2009). (b) Porosity versus P-wave velocity for the samples measured for this study. (c) Facies log and pseudo velocity, density, and porosity logs through the Neist Point and Camas Ban (hyaloclastites) base-basalt transitions. Laboratory measurements coupled with logged geologic observations form the basis of the logs with the gaps filled by inference from literature examples; see the text for details. 
reveal progressive "magma segment" emplacement, inflation, and merging processes (Figure 11a and 11b). In the Vøring Basin examples, the sills are generally dominated by saucer-shaped morphologies (Planke et al., 2005; Polteau et al., 2008); however, many of the intricate emplacement features identified from onshore would be below seismic resolution (e.g., Schofield et al., 2015; Eide et al., 2016).

\section{Hydrothermal vent formation process}

A key focus of this study has been the identification of hydrothermal vent structures emanating from the tips of large dolerite intrusions and cutting up through the preexisting erupted volcanic sequence (Figure 11). These intrusions were emplaced as magma into Jurassic host sediments at Neist Point and into sediments of unknown age on the $\mathrm{VMH}$ at temperatures in the range of approximately $1000^{\circ} \mathrm{C}-1200^{\circ} \mathrm{C}$ (e.g., Hole and Millett, 2016). The heat input associated with the emplacement of large volumes of magma into sill complexes can lead to metamorphic reactions around the sills and to conductive and convective heat transfer (e.g., Aarnes et al., 2015). In the case of the high-TOC Jurassic Lealt shales (Vincent and Tyson, 1999) equivalent to those present at Neist Point, the emplacement of large dolerite intrusions may have caused the production of large volumes of methane $\left(\mathrm{CH}_{4}\right)$ and potentially subordinate volumes of $\mathrm{CO}_{2}$ and $\mathrm{H}_{2} \mathrm{O}$ from less

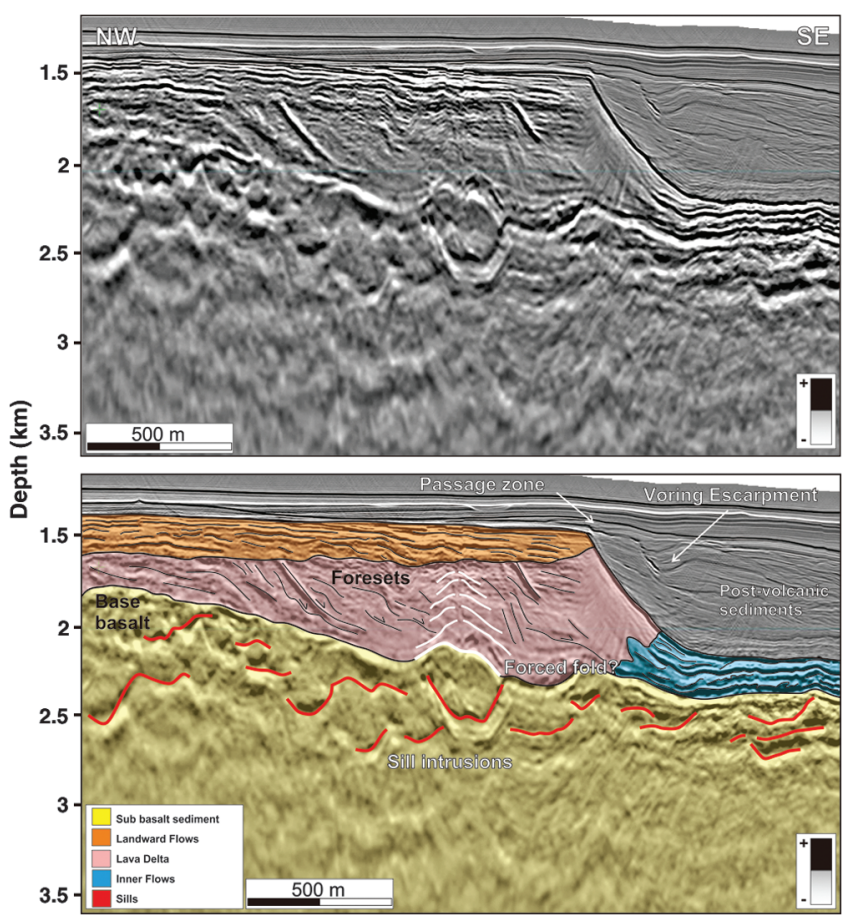

Figure 9. (a) Seismic line from the VMH across the Vøring Escarpment, offshore Norway (CVX1101 3D seismic survey). (b) Interpreted section displaying clear lava-fed delta progradation recognized by the presence of foreset-dipping features. A possible forced-fold structure is observed above a saucershaped sill emplaced immediately beneath the base-basalt transition. dominant calcareous lithologies (Aarnes et al., 2011; Svensen et al., 2015). If the volume of generated fluids was large and the host-rock permeability was low (e.g., shale) and/or capped (e.g., by a lava pile with very low vertical permeability), significant overpressure would have built up in association with the metamorphic aureole of the larger intrusions (Aarnes et al., 2011; Iyer et al., 2013). If the buildup of pressure is great enough to exceed the overburden pressure above intrusions, catastrophic overburden failure and the development of HVCs can occur (Figure 11c; Planke et al., 2005; Aarnes et al., 2011, 2012). This process is envisaged to have occurred above the large dolerite intrusion within the Neist Point area, with pore-water boiling (see Jamtveit et al., 2004) and magma degassing potentially contributing to the generation of overpressure.

Hydrothermal vents are observed in association with sill intrusions in many localities around the world from field and seismic examples (e.g., Jamtveit et al., 2004; Svensen et al., 2004, 2006). The field examples recorded within this study, however, comprise, to our knowledge, the first documented occurrences of hydrothermal vents, closely linked to the intrusions responsible for their formation, breaching an overlying volcanic sequence. Given the challenges associated with imaging features and structures beneath the volcanic cover from offshore (Thompson [2007] provides some examples),

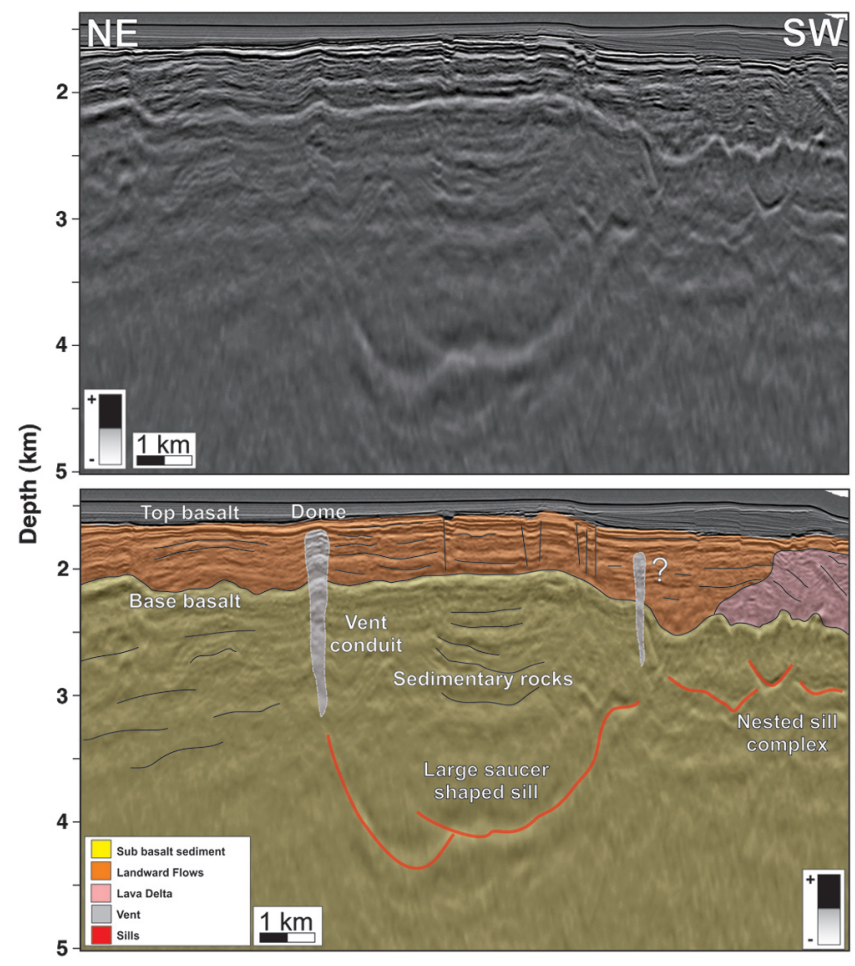

Figure 10. (a) Seismic line from the VMH, offshore Norway (crossline 3575, CVX1101 3D seismic survey). (b) Interpretation of the volcanic succession, which comprises subaerial lava sequences, intruded sedimentary rock formations, and venting structures cutting up through the volcanic pile. The main sill displays a classic saucer-shaped morphology (Planke et al., 2005). 
our results provide evidence for the likely wider presence of these processes within the huge basalt-covered areas of sedimentary basins within the NAIP. This study provides observations that should improve the identification and interpretation of more offshore examples going forward that may have important implications for climate modeling as discussed in the next section.

\section{Implications for the PETM}

It has been hypothesized that the gas release $\left(\mathrm{CH}_{4}\right.$ and $\mathrm{CO}_{2}$ ) from intrusion-related venting along the Northeast Atlantic conjugate margins significantly contributed to the global warming associated with the Palaeocene Eocene thermal maximum (PETM) (e.g., Svensen et al., 2004; Arnes et al., 2015; Jones et al., 2016). This hypothesis was based on the imaging and analysis of intrusions, host rocks, and associated hydrothermal vents within the Vøring and Møre Basins, offshore Norway (Svensen et al., 2004). The areas mapped within this study were largely free from extrusive volcanics, partly due to poor imaging, and partly due to significantly fewer available seismic data from the volcanic covered areas. A key implication of the identification of hydrothermal venting beneath the volcanic covered areas of the NAIP is the potential role that these potentially large numbers of unidentified vents and their associated outgassing may have had on the PETM. Additional study into the vast offshore areas covered by volcanics within the NAIP and other LIPs coupled with new and improved seismic data coverage may therefore significantly influence our understanding of the links between large-scale volcanic episodes and the global climate. In addition, this onshore evidence may also have implications for petroleum exploration within these same regions. If large volumes of methane $(>1150 \mathrm{Gt})$ were potentially produced by extensive intrusions into organic-rich sediments (e.g., Aarnes et al., 2015), beneath these offshore lava piles, then the potential for unconventional petroleum systems similar to those found within the Neuquén Basin, Argentina (Wiite et al., 2012), may be operational and exploitable in the future. The formation of focused breccia pathways cutting through what are generally regarded to be vertically very low permeability lava sequences (e.g., Millett et al., 2015), also has implications for hydrocarbon migration and the potential feeding of supra or intrabasalt prospects.

\section{Future study}

This paper highlights a clear onshore example of a sill intrusion and associated hydrothermal vent cutting through a previously emplaced lava pile at Neist Point, Isle of Skye. We compare this field example with offshore seismic examples from the Vøring Basin, Norway. The historical lack of good seismic resolution within the subbasalt realm has precluded the identification of similar examples, making this study important for highlighting the likely presence of these features going forward in the huge geographical areas where they have until now not been evaluated. Developments in seismic data acquisition and improved subbasalt image processing are ongoing with incremental but tangible improvements. We therefore predict that with improving seismic data, a larger number and wider distribution of intrusion-induced HVCs will start to be identified within the subbasalt domain going forward with associated implications for climatic and petroleum systems.

In relation to the basalt-sediment transition, we also present new petrophysical data targeted at constraining the petrophysical variations that exist at the transition associated with variations in the style of volcanism and environment present at the onset of volcanism. The results from this study already clearly demonstrate the wide variations in these properties between dry and subaqueous settings, in turn highlighting that these transitions will look distinctly different in seismic data. The common presence of intrusions is also demonstrated to significantly alter the physical properties of the transition and therefore should be carefully considered when interpreting seismic data. Future work to characterize additional styles of the basalt-sediment transition is
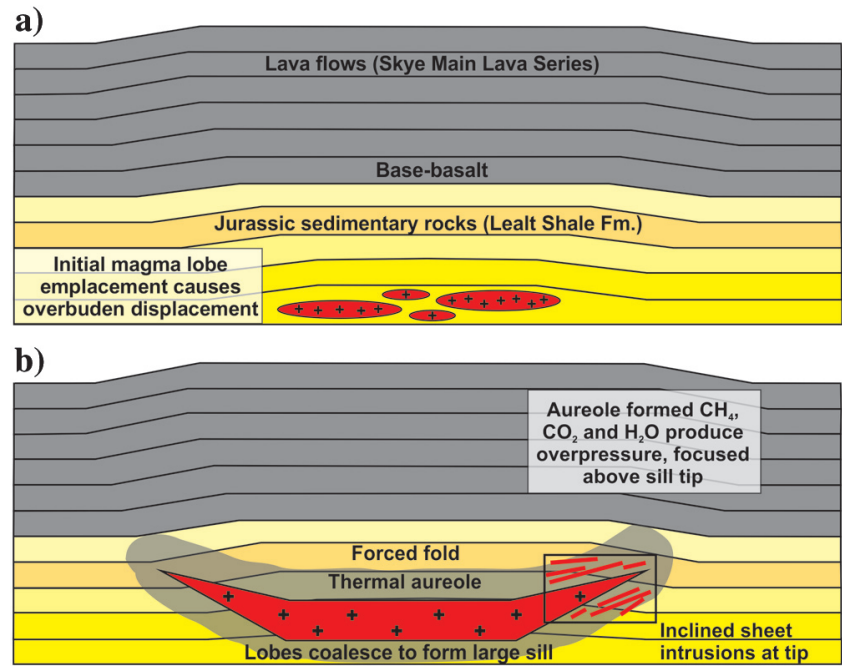

c)

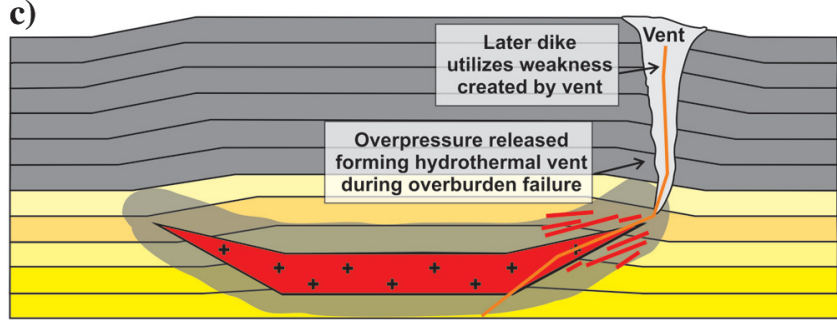

Figure 11. Schematic evolution model for the generation of the HVC identified at Neist Point, Isle of Skye. (a) Initial magma emplacement and overburden deformation. (b) Host-rock metamorphism and overpressure generation caused by metamorphic reactions within the ponded sill aureole producing $\mathrm{CH}_{4}, \mathrm{CO}_{2}$, and $\mathrm{H}_{2} \mathrm{O}$. (c) Overburden stresses are overcome by the overpressure causing catastrophic failure of the overlying lava pile and the formation of a hydrothermal vent breccia. A dike, associated with a subsequent intrusion pulse, uses the weakness caused by the vent structure to migrate up through the lava pile. 
underway and will benefit from synthetic seismic modeling.

\section{Conclusions}

In this study, we have presented new field, laboratory petrophysical, and seismic-based analysis of the complex interaction between dolerite intrusions and host sediments within the NAIP, with a focus on the basalt-sediment transition. From our investigations, we can draw the following conclusions:

- The volcanic facies structure and associated physical properties of the base-basalt transition are widely different depending on the availability of water at the onset of LIP volcanism.

- Due to the wide-scale velocity heterogeneity found within lava piles and their scattering effects on seismic waves, the identification of intrusions and associated vent structures beneath and within lava piles in the subsurface is significantly more challenging than in conventional sedimentary basin settings.

- In this study, we have presented details on HVCs associated with the emplacement of large dolerite sills cutting through the extensive lava sequences of the NAIP from onshore and offshore settings. This provides the first documented example of venting through the lava sequences, and provides valuable information about the relative timing of volcanic events on Skye.

- The onshore example from Neist Point on the Isle of Skye gives an exceptional example of the characteristics and structures from such vent breccias, and it will enable improved understanding of potential subsurface examples going forward.

- Given the presented evidence for venting originating beneath the lava piles of the NAIP along with the known imaging problems associated with these settings, it is entirely possible that a far greater number of these features exist in the subsurface than have previously been appreciated.

- The case for intrusion-related hydrothermal venting processes, such as methane outgassing on climate, e.g., the PETM and other global events, may be significantly strengthened by the future consideration of these huge unquantified areas.

- Finally, the effects of intrusions and associated hydrothermal venting on source-rock maturation, methane generation, compartmentalization, and migration pathways within the subbasalt petroleum systems context may also be significant.

\section{Acknowledgments}

K. Senger, C. Galerne, and C. Magee are thanked for insightful reviews, which significantly improved an earlier version of the manuscript. C. Jackson is also kindly thanked for his editorial handling of the manuscript. We would like to thank the Research Council of Norway for support through its Centre of Excellence funding scheme, project no. 223272. S. Akhavan, B. Løken Berg, M. Erambert, and T. A. Thorsen as senior technical engineer at the University of Oslo, Norway, are appreciated for help during the M.S. project of S. Angkasa at the University of Oslo. K. Mair and K. Senger also provided useful discussion points pertinent to this paper during the M.S. viva of S. A. David Healy and C. Taylor are thanked for help during petrophysical analysis at the University of Aberdeen. Moreover, we also thank D. Marhajan (VBPR) for providing assistance with the seismic data (CVX1101 3D seismic survey).

\section{References}

Aarnes, I., K. Fristad, S. Planke, and H. H. Svensen, 2011, The impact of host-rock composition on devolatilization of sedimentary rocks during contact metamorphism around mafic sheet intrusions: Geochemistry, Geophysics, Geosystems, 12, Q10019, doi: 10.1029/2011GC003636.

Aarnes, I., S. Planke, M. Trulsvik, and H. H. Svensen, 2015, Contact metamorphism and thermogenic gas generation in the Vøring and Møre basins, offshore Norway, during the Paleocene-Eocene thermal maximum: Journal of the Geological Society, 172, 588-598, doi: 10 .1144/jgs2014-098.

Aarnes, I., Y. Y. Podladchikov, and H. H. Svensen, 2012, Devolatilization-induced pressure build-up: Implications for reaction front movement and Breccia pipe formation: Geofluids, 12, 265-279, doi: 10.1111/j.1468-8123 .2012.00368.x.

Aarnes, I., H. H. Svensen, J. A. D. Connolly, and Y. Y. Podladchikov, 2010, How contact metamorphism can trigger global climate changes: Modelling gas generation around igneous sills in sedimentary basins: Geochimica et Cosmochimica Acta, 74, 7179-7195, doi: 10.1016/j .gca.2010.09.011.

Abdelmalak, M. M., S. Planke, J. I. Faleide, D. A. Jerram, D. Zastrozhnov, S. Eide, and R. Myklebust, 2016, The development of volcanic sequences at rifted margins: New insights from the structure and morphology of the Vøring Escarpment, mid-Norwegian Margin: Journal Geophysical Research: Solid Earth, 121, 5212-5236.

Barr, S. M., and M. A. Cooper, 2013, Late Cenozoic basalt and gabbro in the subsurface in the Phetchabun Basin, Thailand: Implications for the Southeast Asian volcanic province: Journal of Asian Earth Sciences, 76, 169-184, doi: 10.1016/j.jseaes.2013.01.013.

Berndt, C., S. Planke, E. Alvestad, F. Tsikalas, and T. Rasmussen, 2001, Seismic volcano stratigraphy of the Norwegian Margin: Constraints on tectonomagmatic break-up processes: Journal of the Geology Society, 158, 413-426, doi: 10.1144/jgs.158.3.413.

Bjørnseth, H. M., S. M. Grant, E. K. Hansen, J. R. Hossack, D. G. Roberts, and M. Thompson, 1997, Structural evolution of the Vøring Basin, Norway, during the Late Cretaceous and Palaeogene: Journal of the Geological Society, 154, 559-563, doi: 10.1144/gsjgs.154.3.0559. 
Davison, I., S. Stasiuk, P. Nuttall, and P. Keane, 2010, Subbasalt hydrocarbon prospectivity in the Rockall, FaroeShetland and Møre basins, NE Atlantic: Geological Society of London, Special Publications, 1025-1032.

Delpino, D. H., H. Daniel, and A. M. Bermúdez, 2009, Petroleum systems including unconventional reservoirs in intrusive igneous rocks (sills and laccoliths): The Leading Edge, 28, 804-811, doi: 10.1190/1.3167782.

Ebinghaus, A., J. H. Adrian, D. W. Jolley, M. J. Hole, and J. M. Millett, 2014, Lava-sediment interaction and drainage-system development in a large igneous province: Columbia River flood basalt province, Washington State, U.S.A: Journal of Sedimentary Research, 84, 1041-1063, doi: $10.2110 /$ jsr.2014.85.

Eide, C. H., N. Schofield, D. A. Jerram, and J. A. Howell, 2016, Basin-scale architecture of deeply emplaced sill complexes: Jameson Land, East Greenland: Journal of the Geological Society, 174, 23-40, doi: 10.1144/jgs2016018.

Emeleus, C. H., and R. H. Bell, 2005, British Regional Geology: The Palaeogene Volcanic Districts of Scotland, 4th ed.: British Geological Survey.

England, R. W., R. W. H. Butler, and D. H. W. Hutton, 1993, The role of Paleocene magmatism in the Tertiary evolution of basins on the NW seaboard: Geological Society of London, Special Publications, 97-105.

Farrell, N. J. C., D. Healy, and C. W. Taylor, 2014, Anisotropy of permeability in faulted porous sandstones: Journal of Structural Geology, 63, 50-67, doi: 10 .1016/j.jsg.2014.02.008.

Filho, A. T., A. M. Pimentel, and L. Antonioli, 2008, Magmatism and petroleum exploration in the Brazilian Paleozoic basins: Marine and Petroleum Geology, 25, 143-151, doi: 10.1016/j.marpetgeo.2007.07.006.

Gallagher, J. W., and P. W. Dromgoole, 2007, Exploring below the basalt, offshore Faroes: A case history of subbasalt imaging: Petroleum Geoscience, 13, 213-225, doi: 10.1144/1354-079306-711.

Ganino, C., and N. T. Arndt, 2009, Climate changes caused by degassing of sediments during the emplacement of large igneous provinces: Geology, 37, 323-326, doi: 10.1130/G25325A.1.

Hafeez, A., S. Planke, D. A. Jerram, J. M. Millett, D. Maharjan, and T. Prestvik, 2017, Upper paleocene ultramafic igneous rocks offshore Mid-Norway: Re-interpretation of the Vestbrona Formation as a sill complex: Interpretation, 5, this issue, doi: 10.1190/int-2016-0143.1.

Harris, J. P., 1989, The sedimentology of a Middle Jurassic lagoonal delta system: Elgol Formation (Great Estuarine Group), NW Scotland: Special Publication of the Geological Society, 41, 147-166, doi: 10.1144/GSL.SP 1989.041.01.12.

Hamilton, M. A., D. G. Pearson, R. N. Thompson, S. P. Kelley, and C. H. Emeleus, 1998, Rapid eruption of Skye Lavas inferred from precise U-Pb and Ar-Ar dating of the Rum and Cuillin plutonic complexes: Nature, 394, 260-263.
Hansen, D. M., and J. Cartwrigth, 2006, Saucer-shaped sill with lobate morphology revealed by 3D seismic data: Implication for resolving a shallow-level sill emplacement mechanism: Geological Society of London, Special Publications, 163, 509-523, doi: 10.1144/0016-764905-073.

Hansen, J., D. A. Jerram, K. McCaffrey, and S. R. Passey, 2009, The onset of the North Atlantic igneous province in a rifting perspective: Geological Magazine, 146, 309325, doi: 10.1017/S0016756809006347.

Hansen, J., D. A. Jerram, K. McCaffrey, and S. R. Passey, 2011, Early Cenozoic saucer-shaped sills of the Faroe Islands: An example of intrusive styles in basaltic lava piles: Journal of Geological Society, 168, 159-178, doi: 10.1144/0016-76492010-012.

Hesselbo, S. P., and A. L. Coe, 2000, Jurassic sequences of the Hebrides Basin, Isle of Skye, Scotland, in J. R. Graham, and A. Ryan, eds., Field trip guidebook: International Association of Sedimentologists Meeting, 41-58.

Hole, M. J., and J. M. Millett, 2016, Controls of Mantle Potential Temperature and Lithospheric Thickness on Magmatism in the North Atlantic Igneous Province: Journal of Petrology, 57, 417-436, doi: 10.1093/ petrology/egw1014.

Hole, M. J., J. M. Millett, N. W. Rogers, and D. W. Jolley, 2015, Rifting and mafic magmatism in the Hebridean basins: Journal of the Geological Society, 172, 218-236, doi: 10.1144/jgs2014-100.

Hutton, D. H. W., 2009, Insights into magmatism in volcanic margins: Bridge structures and a new mechanism of basic sill emplacement Theron Mountains, Antarctica: Petroleum Geoscience, 15, 269-278, doi: 10.1144/ 1354-079309-841.

Iyer, K., L. Rüpke, and C. Y. Galerne, 2013, Modeling fluid flow in sedimentary basins with sill intrusions: Implications for hydrothermal venting and climate change: Geochemistry, Geophysics, Geosystems, 14, 52445262, doi: 10.1002/ggge.v14.12.

Jackson, C. A. L., N. Schofield, and B. Golenkov, 2013, Geometry and controls on the development of igneous sill-related forced folds: A 2-D seismic reflection case study from offshore southern Australia: Geological Society of America Bulletin, 125, 1874-1890, doi: 10.1130/B30833.1.

Jamtveit, B., H. H. Svensen, Y. Y. Podladchikov, and S. Planke, 2004, Hydrothermal vent complexes associated with sill intrusions in sedimentary basins: Physical geology of high-level magmatic systems, 234, 233-241.

Jerram, D. A., 2002, Volcanology and facies architecture of flood basalts: Geological Society of America Special Papers, 362, 119-132, doi: 10.1130/0-8137-2362-0.119.

Jerram, D., 2015, Hot rocks and oil: Are volcanic margins the new frontier?: Elsevier R\&D Solutions.

Jerram, D. A., and S. E. Bryan, 2015, Plumbing systems of shallow level intrusive complexes: Advances in volcanology: Springer.

Jerram, D. A., R. T. Single, R. W. Hobbs, and C. E. Nelson, 2009, Understanding the offshore flood basalt sequence 
using onshore volcanic facies analogues: An example from the Faroe-Shetland Basin: Geological Magazine, 146, 353-367, doi: 10.1017/S0016756809005974.

Jerram, D. A., and M. Widdowson, 2005, The anatomy of Continental Flood Basalt Provinces: geological constraints on the processes and products of flood volcanism: Lithos, 79, 385-405, doi: 10.1017/S0016756809005974.

Jerram, D. A., H. H. Svensen, S. Planke, A.G. Polozov, and T. H. Torsvik, 2016a, The onset of flood volcanism in the north-western part of the Siberian Traps: Explosive volcanism versus effusive lava flows: Palaeogeography, Palaeoclimatology, Palaeoecology, 441, 38-50, doi: 10 .1016/j.palaeo.2015.04.022.

Jerram, D. A., M. Widdowson, P. B. Wignall, Y. Sun, X. Lai, D. P. G. Bond, and T. H. Torsvik, 2016b, Submarine palaeoenvironments during Emeishan flood basalt volcanism, SW China: Implications for plume-lithosphere interaction during the Capitanian, Middle Permian ('end Guadalupian') extinction event: Palaeogeography, Palaeoclimatology, Palaeoecology, 441, 65-73, doi: 10 .1016/j.palaeo.2015.06.009.

Jolley, D. W., S. R. Passey, M. J. Hole, and J. M. Millett, 2012, Large-scale magmatic pulses drive plant ecosystem dynamics: Journal of the Geological Society, 169, 703-711, doi: 10.1144/jgs2012-012.

Jones, M. T., D. A. Jerram, H. H. Svensen, and C. Grove, 2016, The effects of large igneous provinces on the global carbon and sulphur cycles: Palaeogeography, Palaeoclimatology, Palaeoecology, 441, 4-21, doi: 10 .1016/j.palaeo.2015.06.042.

Magee, C., B. O’Driscoll, M. S. Petronis, C. T. E. Stevenson, P. L. Clay, and R. Gertisser, 2013, Magma rheology variations in sheet intrusions of the Ardnamurchan Central Complex (Scotland) inferred from gabbro inclusion characteristics: Journal of Petrology, 54, 75-102, doi: 10.1093/petrology/egs064.

Magee, C., J. D. Muirhead, A. Karvelas, S. P. Holford, C. A. L. Jackson, I. D. Bastow, N. Schofield, C. T. E. Stevenson, C. McLean, W. McCarthy, and O. Shtukert, 2016, Lateral magma flow in mafic sill complexes: Geosphere, 12, 809-841, doi: 10.1130/GES01256.1.

Millett, J. M., M. J. Hole, D. W. Jolley, N. Schofield, and E. Campbell, 2015, Frontier exploration and the North Atlantic igneous province: New insights from a $2.6 \mathrm{~km}$ offshore volcanic sequence in the NE Faroe-Shetland Basin: Journal of the Geological Society, 173, 320 336, doi: 10.1144/jgs2015-069.

Millett, J. M., A. D. Wilkins, E. Campbell, M. J. Hole, R. A. Taylor, D. Healy, D. A. Jerram, D. W. Jolley, S. Planke, S. G. Archer, and A. Blischke, 2016, The geology of offshore drilling through basalt sequences: Understanding operational complications to improve efficiency: Marine and Petroleum Geology, 77, 1177-1192, doi: 10.1016/j.marpetgeo.2016.08.010.

Morton, N., 1983, Palaeocurrents and palaeo-environment of part of the Bearreraig Sandstone (Middle Jurassic) of
Skye and Raasay, Inner Hebrides: Scottish Journal of Geology, 19, 87-95, doi: 10.1144/sjg19010087.

Morton, N., 1999, Middle Hetangian (Lower Jurassic) ammonites from Isle of Raasay, Inner Hebrides and correlation of the Hetangian-lowermost Sinemurian Breakish Formation in the Skye area, NW Scotland: Scottish Journal of Geology, 35, 119-130, doi: 10.1144/sjg35020119.

Nelson, C. E., D. A. Jerram, and R. W. Hobbs, 2009, Flood basalt facies from borehole data: Implications for prospectivity and volcanology in volcanic rifted margins: Petroleum Geoscience, 15, 313-324, doi: 10.1144/ 1354-079309-842.

Nelson, C. E., D. A. Jerram, R. T. Single, and R. W. Hobbs, 2009, Understanding the facies architecture of flood basalts and volcanic rifted margins and its effect on geophysical properties, in T. Varming, and H. Ziska, eds., Faroe Islands Exploration Conference, Proceedings of the 2nd Conference (Annales Societatis Scientarium Faroensis), 215-234.

Pedersen, G. K., L. M. Larsen, A. K. Pedersen, and B. F. Hjortkjær, 1998, The syn-volcanic Naajaat lake, Paleocene of West Greenland: Palaeogeography, Palaeoclimatology, Palaeoecology, 140, 271-287.

Planke, S., 1994, Geophysical response of flood basalts from analysis of wire line logs: Ocean Drilling Program Site 642, Vøring volcanic margin: Journal of Geophysical Research: Solid Earth, 99, 9279-9296, doi: 10.1029/94JB00496.

Planke, S., and E. Alvestad, 1999, Seismic volcanostratigraphy of the extrusive breakup complexes in the northeast Atlantic: Implications from ODP/DSDP drilling: Proceedings of the Ocean Drilling Program: Scientific Results, 163, 3-16.

Planke, S., T. Rasmussen, S. S. Rey, and R. Myklebust, 2005, Seismic characteristics and distribution of volcanic intrusions and hydrothermal vent complexes in the Vøring and Møre Basins: Geological Society of London, Special Publications, 6, 833-844, doi: 10.1144/0060833.

Planke, S., P. A. Symonds, E. Avelstad, and J. Skogseid, 2000, Seismic volcanostratigraphy of large-volume basaltic extrusive complexes on rifted margins: Journal of Geophysical Research: Solid Earth, 105, 1933519351, doi: 10.1029/1999JB900005.

Planke, S., J. M. Millett, D. Maharjan, D. A. Jerram, M. M. Abdelmalak, A. Groth, J. Hoffmann, C. Berndt, and R. Myklebust, 2017, Igneous seismic geomorphology of buried lava fields and coastal escarpments on the Vøring volcanic rifted margin: Interpretation, 5, this issue, doi: 10.1190/int-2016-0164.1.

Planke, S., H. H. Svensen, R. Myklebust, S. Bannister, B. Manton, and L. Lorenz, 2015, Geophysics and remote sensing: Advances in Volcanology: Springer.

Pollard, D. D., and A. M. Johnson, 1973, Mechanics of growth of some laccolithic intrusions in the Henry Mountains, Utah — Part 2: Bending and failure of overburden layers and sill formation: Tectonophysics, 18, 311-354, doi: 10.1016/0040-1951(73)90051-6. 
Polteau, S., E. C. Ferré, S. Planke, E. R. Neumann, and L. Chevallier, 2008, How are saucer-shaped sills emplaced? Constraints from the Golden Valley Sill, South Africa: Journal of Geophysical Research: Solid Earth, 113, B12.

Rateau, R., N. Schofield, and M. Smith, 2013, The potential role of igneous intrusions on hydrocarbon migration, West of Shetland: Petroleum Geoscience, 19, 259-272, doi: 10.1144/petgeo2012-035.

Roberts, D., 2003, The Scandinavian Caledonides: Event chronology, palaeogeographic settings and likely modern analogues: Tectonophysics, 365, 283-299, doi: 10.1016/ S0040-1951(03)00026-X.

Rozhko, A. Y., Y. Y. Podladchikov, and F. Renard, 2007, Failure patterns caused by localized rise in porefluid overpressure and effective strength of rocks: Geophysical Research Letters, 34, L22304, doi: 10.1029/ 2007 GL031696.

Saunders, A. D., J. G. Fitton, A. C. Kerr, M. J. Norry, and R. W. Kent, 1997, The North Atlantic igneous province: Large igneous provinces: Continental, oceanic, and planetary flood volcanism, in J. J. Mahoney, and M. F. Coffin, eds., American Geophysical Union, 45-93.

Schofield, N., D. J. Brown, C. Magee, and C. T. Stevenson, 2012, Sill morphology and comparison of brittle and non-brittle emplacement mechanisms: Journal of the Geological Society, 169, 127-141, doi: 10.1144/001676492011-078.

Schofield, N., D. A. Jerram, S. Holford, A. Stuart, M. Niall, A. Hartley, J. Howell, M. David, P. Green, D. Hutton, and C. Stevenson, 2016, Sills in sedimentary basin and petroleum systems, in K. Németh, ed., The Series Advances in Volcanology, 1-22.

Schofield, N., and D. J. Jolley, 2013, Development of intrabasaltic lava-field drainage systems within the FaroeShetland Basin: Petroleum Geoscience, 19, 273-288, doi: 10.1144/petgeo2012-061.

Schofield, N., S. Holford, J. M. Millett, D. Brown, D. Jolley, S. R. Passey, D. Muirhead, C. Grove, C. Magee, J. Murray, M. Hole, C. A. L. Jackson, and C. Stevenson, 2015, Regional magma plumbing and emplacement mechanisms of the Faroe-Shetland Sill Complex: Implications for magma transport and petroleum systems within sedimentary basins: Basin Research, 29, 41-63, doi: 10.1111/bre.12164.

Schutter, S. R., 2003, Hydrocarbon occurrence and exploration in and around igneous rocks: Geological Society of London, Special Publications, 214, 7-33, doi: 10.1144/ GSL.SP.2003.214.01.02.

Searl, A., 1992, Sedimentology and early diagenesis of Bradford Beds (Lower Jurassic), Skye, north-west Scotland: Geological Journal, 27, 243-270, doi: 10.1002/ (ISSN)1099-1034.

Searl, A., 1994, Diagenetic destruction of reservoir potential in shallow marine sandstones of Bradford Beds (Lower Jurassic), north-west Scotland: Depositional versus burial and thermal history controls on porosity destruction: Marine and Petroleum Geology, 11, 131147, doi: 10.1016/0264-8172(94)90090-6.

Stein, A. M., 1988, Basement controls upon basin development in the Caledonian foreland, NW Scotland: Basin Research, 1, 107-119, doi: 10.1111/j.1365-2117.1988 .tb00008.x.

Single, R. T., and D. A. Jerram, 2004, The 3D facies architecture of flood basalt provinces and their internal heterogeneity: Examples from the Palaeogene Skye Lava Field: Journal of the Geological Society, 161, 911-926, doi: 10.1144/0016-764903-136.

Skilling, I. P., 2002, Basaltic pahoehoe lava-fed deltas: large-scale characteristics, clast generation, emplacement processes and environmental discrimination: Geological Society, London, Special Publications, 202, 91113, doi: 10.1144/gsl.sp.2002.202.01.06.

Smallwood, J. R., and J. Maresh, 2002, The properties, morphology and distribution of igneous sills: modelling, borehole data and 3D seismic from the Faroe-Shetland area: Geological Society, London, Special Publications, 197, 271-306, doi: 10.1144/gsl.sp.2002.197.01.11.

Sørenssen, A. M., S. Planke, H. H. Svensen, and B. Jamtveit, 2004, Formation of saucer-shaped sills: Geological Society of London, Special Publications, 234, 215-227, doi: 10.1144/GSL.SP.2004.234.01.13.

Svensen, H. H, K. E. Fristad, A. G. Polozov, and S. Planke, 2015, Volatile generation and release continental large igneous provinces, in A. Schmidt, K. E. Fristad, and L. T. Elkins-Tanton, eds., Volcanism and Global Environmental Change: Cambridge University Press, doi: 10 .1017/CBO9781107415683.

Svensen, H. H., B. Jamtveit, S. Planke, and L. Chevallier, 2006, Structure and evolution of hydrothermal vent complexes in the Karoo Basin, South Africa: Journal of the Geological Society, 163, 671-682, doi: 10.1144/ 1144-764905-037.

Svensen, H. H., S. Planke, L. Chevallier, A. M. Sørenssen, F. Corfu, and B. Jamtveit, 2007, Hydrothermal venting of greenhouse gases triggering Early Jurassic global warming: Earth and Planetary Science Letters, 256, 554-566, doi: 10.1016/j.epsl.2007.02.013.

Svensen, H. H., S. Planke, and F. Corfu, 2010, Zircon dating ties NE Atlantic sill emplacement to initial Eocene global warming: Journal of the Geological Society, 167, 433-436, doi: 10.1144/0016-76492009-125.

Svensen, H. H., S. Planke, A. M. Sørenssen, B. Jamtveit, R. Myklebust, E. T. Rasmussen, and S. S. Rey, 2004, Release of methane from a volcanic basin as a mechanism for initial Eocene global warming: Nature, 429, 542-545, doi: 10.1038/nature02566.

Thomson, K., and D. Hutton, 2004,Geometry and growth of sill complexes: Insights using 3D seismic from the North Rockaal Trough: Bulletin of Volcanology, 66, 364-375, doi: 10.1007/s00445-003-0320-z.

Thomson, K., and N. Schofield, 2008, Lithological and structural controls on the emplacement and morphol- 
ogy of sills in sedimentary basins: Geological Society of London, Special Publications, 302, 31-44, doi: 10.1144/ SP302.3.

Thompson, K., 2007, Determining magma flow in sills, dykes and laccoliths and their implications for sill emplacement mechanisms: Bulletin of Volcanology, 70, 183-201, doi: 10.1007/s00445-007-0131-8.

Trewin, N. H., 2002, The geology of Scotland: Geological Society of London, Special Publications.

Trude, K. J., 2004, Kinematic indicators for shallow level igneous intrusions from 3D seismic data: Evidence of flow direction and feeder location, in R. J. Davies, J. A. Cartwright, S. A. Stewart, M. Lappin, and J. R. Underhill, eds., 3D seismic technology: Application to the exploration of sedimentary basins: Geological Society of London Memoir, 209-218.

Watton, T. J., D. A. Jerram, T. Thordarson, and R. J. Davies, 2013, Three-dimensional lithofacies variations in hyaloclastite deposits: Journal of Volcanology and Geothermal Research, 250, 19-33, doi: 10.1016/j.jvolgeores .2012.10.011.

Watton, T. J., K. A. Wright, D. A. Jerram, and R. J. Brown, 2014, The petrophysical and petrographical properties of hyaloclastite deposits: Implications for petroleum exploration: AAPG Bulletin, 98, 449-463, doi: 10.1306/ 08141313029.

Witte, J., M. Bonora, C. Carbone, and O. Oncken, 2012, Fracture evolution in oil-producing sills of the Rio Grande Valley, northern Neuquén Basin, Argentina: AAPG Bulletin, 96, 1253-1277, doi: 10.1306/10181110152.

Wright, K. A., R. J. Davies, D. A. Jerram, J. Morris, and R. Fletcher, 2012, Application of seismic and sequence stratigraphic concepts to a lava-fed delta system in the Faroe-Shetland Basin, UK and Faroes: Basin Research, 24, 91-106, doi: 10.1111/j.1365-2117.2011.00513.x.

Viereck, L. G., J. Hertogen, L. M. Parson, A. C. Morton, D. Love, and I. L. Gibson, 1989, Chemical stratigraphy and petrology of the Vøring Plateau tholeiitic lavas and interlayered volcaniclastic sediments at ODP Hole 642E1: Proceedings of the Ocean Drilling Program, 104, 367-396.

Vincent, A. J., and R. V. Tyson, 1999, Organic facies of the Middle Jurassic of the Inner Hebrides, Scotland: Petroleum Geoscience, 5, 83-92, doi: 10.1144/petgeo.5.1.83.

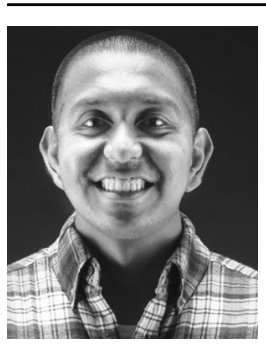

Syahreza S. Angkasa received a B.S. in geology from the Universitas Padjadjaran, Indonesia. He then worked as an exploration geologist at Freeport Mcmoran Copper-Gold in Indonesia for two years. In 2016, he completed his M.S. degree in geoscience at the University of Oslo, Norway under the supervision of Dougal A. Jerram, Henrik H. Svensen, and John M. Millett. He is now pursuing Ph.D. degree at Akita University, Japan.

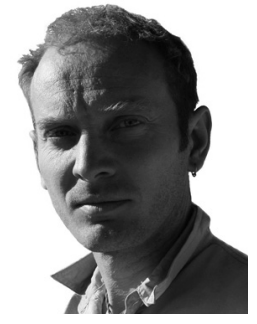

Dougal A. Jerram is the director of DougalEARTH Ltd. (www.dougalearth.com), and Prof II at the Centre for Earth Evolution and Dynamics, the University of Oslo. He is an award winning earth scientist (Geol. Soc. Murchison Fund 2006) and has worked for many years on projects that link academia and industry as an expert in volcanic rocks and volcanic margins. With many publications, and an author of books, he also undertakes science outreach activities through the media. The most recent major venture is called Volcanic Margin Petroleum Prospectivity (VMAPP), which is a multiclient project undertaken with Volcanic Basin Petroleum Research (VBPR) and TGS, looking at our state of the art understanding of volcanics in the petroleum context.

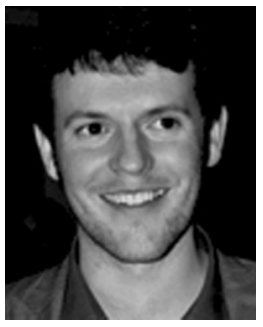

John M. Millett received a first-class B.S. Hons (2010) in geology and petroleum geology from the University of Aberdeen followed by a Ph.D. (2014). He works for VBPR AS and holds an honorary research fellow position at the University of Aberdeen. He is a member of the Mineralogical Society and is a member of the VMSG committee. He has a wide experience in volcanic basins with expertise covering igneous geochemistry, stratigraphy, petrophysics, borehole analysis, and petroleum systems.

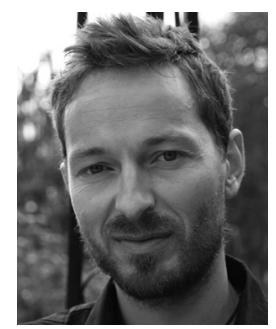

Henrik H. Svensen is a research professor at the Centre for Earth Evolution and Dynamics (CEED), the University of Oslo, Norway. He is working on understanding the links between large igneous provinces and environmental crises, including the end-Permian, the end-Triassic, the Toarcian, and the PETM. In addition to doing research, he has written several popular science books, including The End is Nigh (about natural disasters) and Bergtatt (about the history of mountains).

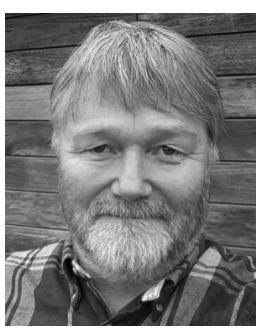

Sverre Planke received a B.S. (1985) in geologic engineering and an M.Sc. (1987) in geophysics from the University of Utah and a Ph.D. (1993) in geology from the University of Oslo. He is the CEO of VBPR and an adjunct professor at the CEED, the University of Oslo, Norway. He is a geoscientist with a research focus on the processes and structure of volcanic-rifted margins and volcanic basins based on integrated geologic, geophysical, and theoretical methods. He is a cofounder of VBPR (1999) and P-Cable 3D Seismic (2007). 


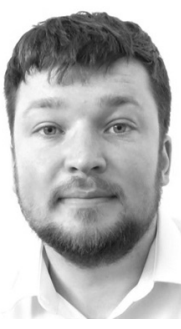

Ross A. Taylor received a bachelor's degree (2010) in petroleum geology from the University of Aberdeen. He then worked as a geologist within the core analysis company Corex for two years. In 2016, he received a $\mathrm{Ph} . \mathrm{D}$. in geology from the University of Aberdeen studying onshore analogues for intrabasaltic reservoir units in the Faroe-Shetland Basin. He works as a clastic sedimentologist for Robertson's (a CGG company) in North Wales, UK.

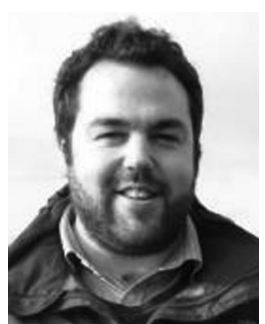

Nick Schofield specializes in the seismic and field interpretation of intrusive and extrusive sequences in volcanic terranes and their interaction with hydrocarbon systems. He is a member of the Volcanic Margins Research Consortium (VMRC), which provides the petroleum industry with training and research expertise in volcanology, sedimentology, and structural geology of volcanic margins.

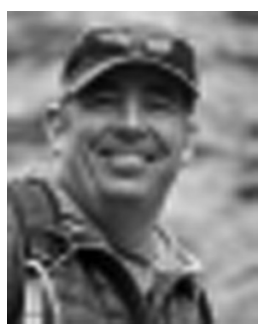

John Howell received a degree from the University of Cardiff, followed by a Ph.D. from the University of Birmingham. He then spent 10 years at the University of Liverpool as a researcher and junior faculty member working with the StratGroup. He moved to Norway in 2002 and lived in Bergen until 2012. During that time, he worked in the department of earth sciences and UniCIPR where he founded the Virtual Outcrop Geology Group. He was also one of the founders of Rocksource ASA, an independent Norwegian E\&P Company, where he worked as part of the senior management team for six years. Since 2012, he has been a professor at the University of Aberdeen. His current research focuses on improved use of analogues for understanding reservoirs. 